\title{
The use of lithogeochemistry in delineating hydrothermal fluid pathways and vectoring gold mineralization in the Malartic district, Québec”
}

\author{
Authors \\ Nicolas Gaillard ${ }^{1}$, Anthony E. Williams-Jones ${ }^{1}$, James R. Clark ${ }^{\text {, Stefano Salvi }}{ }^{2}$, Stéphane Perrouty ${ }^{3,4}$, \\ Robert L. Linnen ${ }^{4}$, Gema R. Olivo ${ }^{5}$
}

\section{Affiliations}

${ }^{l}$ McGill University, Department of Earth and Planetary Sciences, 3450 University Street, Montréal, QC, H3A 0E8, Canada

${ }^{2}$ Géosciences Environnement Toulouse (GET), Université Paul Sabatier, CNRS, Institut de Recherche pour le Développement, 14 avenue Edouard Belin, F-31400 Toulouse, France

${ }^{3}$ Laurentian University, Mineral Exploration Research Centre, Harquail School of Earth Sciences, Goodman School of Mines, 935 Ramsey Lake Road, Sudbury, ON, P3E 2C6, Canada

${ }^{4}$ Western University, Department of Earth Sciences, 1151 Richmond Street, London, ON, N6A 6B7, Canada

${ }^{5}$ Queen's University, Department of Geological Sciences and Geological Engineering, Kingston, ON K7L 3N6, Canada

\section{Corresponding author}

Nicolas Gaillard

McGill University, Department of Earth and Planetary Sciences

3450 University Street, Montréal, QC, H3A 0E8, Canada

nicolas.gaillard@mail.mcgill.ca 


\section{Abstract}

The Canadian Malartic world-class low grade, large tonnage gold deposit is located in the southeastern

3 Superior Province of Canada. With reserves estimated at 6.38 Moz Au grading $1.10 \mathrm{~g} / \mathrm{t} \mathrm{Au}$, it is currently the largest open pit mine in the Abitibi gold camp. The deposit is hosted predominantly by Pontiac Group metasedimentary rocks, Piché Group metavolcanic rocks, and quartz monzodiorite porphyritic intrusions. Stockwork-disseminated gold mineralization generally consists of a low-grade envelope of disseminated pyritic ore $(0.35$ to $1 \mathrm{~g} / \mathrm{t} \mathrm{Au})$ grading inwards into higher grade $(>1 \mathrm{~g} / \mathrm{t} \mathrm{Au})$ stockwork and breccia zones. Hydrothermal alteration in the metasedimentary rocks displays a consistent zonation with distance from the main fluid pathways. Proximal alteration is characterized by a microcline \pm albite-quartz replacement-type assemblage, with lesser phlogopite, calcite \pm Fe-dolomite, pyrite and rutile. The distal alteration assemblage

11 is dominated by biotite, microcline \pm albite, phengite, quartz, calcite, pyrite and rutile.

In this study, a lithogeochemical approach is used to assess the magnitude and distribution of fluid-rock

13 interaction in the metasedimentary rocks of the Malartic district. The metaturbidites are separated into four 14 sub-lithologies according to grain size characteristics to reduce the effects of primary depositional processes on mass change calculations. Despite the variability in protolith compositions, the metasedimentary rocks

16 define a geochemically consistent, cogenetic sequence. The results of the mass transfer calculations indicate 17 progressive gains in $\mathrm{C}-\mathrm{S}-\mathrm{K}_{2} \mathrm{O}$ and $\mathrm{LOI}$, as well as $\mathrm{Au}-\mathrm{Te}-\mathrm{W}-\mathrm{Ag} \pm(\mathrm{As}-\mathrm{Be}-\mathrm{Sb}-\mathrm{Bi}-\mathrm{Mo}-\mathrm{Pb})$ from background, through distal to proximal alteration zones (relative to least altered samples). Molar element ratio analysis

19 (alkali/aluminium) indicates an increase in alkali metasomatism ( $\mathrm{K}$ and $\mathrm{Na}$ ) adjacent to the fluid pathways, which is manifested by the progressive stabilization of microcline and albite (at the expense of biotite and white mica).

Ore-associated pathfinder elements delineate broad enrichment patterns around the deposit, and can be used to outline hydrothermal fluid circulations in the Malartic district. A statistical approach based on the comparison of the mass balance results with the background composition provides robust constraints on the magnitude and extent of the lithogeochemical haloes. Most alteration envelopes extend along the $\mathrm{S}_{2}$ fabric, and the largest lithogeochemical anomalies (e.g., $\mathrm{Au}, \mathrm{W}, \mathrm{Te}$ and $\mathrm{Ag}$ ) reach up to 10 kilometers in length,

27 and 2 kilometers in width. These observations demonstrate that whole-rock lithogeochemistry provides a 28 valuable vectoring tool toward gold mineralization in a regional exploration context. 


\section{Introduction}

Major gold deposits in metamorphic terranes are typically surrounded by extensive wall-rock alteration

31 haloes manifested by systematic changes in mineralogy away from the hydrothermal fluid pathways

32 (Clark et al., 1989; Eilu and Mikucki, 1998; Bierlein et al., 1998; Eilu et al., 1999; Bierlein et al., 2000;

33 Knight et al., 2000; Eilu and Groves, 2001; Goldfarb et al., 2005). The lateral zonation of alteration reflects

34 the progressive decrease in fluid-rock interaction with increasing distance (i.e., rock-buffering) from the

35 hydrothermal centers (Khorzinskii, 1968; McCuaig et al., 1993; Ridley et al., 1996). Because the variations

36 in alteration mineralogy are generally commensurate with mass transfer processes, lithogeochemical data

37 can be used to assess the magnitude and spatial distribution of fluid-rock interaction (Bierlein et al., 1998;

38 Eilu et al., 2001; Warren et al., 2007; Whitbread and Moore, 2004; Prendergast, 2007). In particular,

39 methods involving mass balance calculations constitute a quantitative approach to evaluate the effects of

40 metasomatic processes (Gresens, 1967; Grant, 1986; MacLean and Barrett, 1993; Mathieu, 2018).

41 Likewise, molar element ratio analysis can be used to investigate mass transfer processes, and also offers a

42 direct means to interpret alteration-related mineralogical reactions (Madeisky and Stanley, 1993; Warren

43 et al., 2007; Stanley, 2017). The results of mass transfer calculations and molar element ratio analysis

44 therefore provide key parameters for mapping the spatial distribution of alteration that defines the footprint 45 of major gold deposits (Eilu and Mikucki, 1998; Eilu et al., 1999; Whitbread and Moore, 2004; Warren et 46 al., 2007; Stock, 2012). Most notably, ore-related 'pathfinder' elements (e.g., W, Te, Sb, Bi or As) can 47 delineate lithogeochemical anomalies that extend far beyond the limits of the macroscopic hydrothermal 48 alteration (Eilu and Groves, 2001; Whitbread and Moore, 2004; Perrouty et al., 2018).

49 In this study, we characterize the lithogeochemical signature of hydrothermal alteration at the Canadian 50 Malartic stockwork-disseminated gold deposit (Québec), and extract parameters to map the intensity and 51 distribution of fluid-rock interaction. This approach should prove especially useful in a mineral exploration 52 context by providing potential lithogeochemical vectors toward gold mineralization (Warren et al., 2007;

53 Stock, 2012; Halley et al., 2015). For this purpose, mass transfer calculations are conducted to evaluate 54 the magnitude of the metasomatic processes and their spatial distribution across the Malartic district. 55 In addition, molar element ratios are used to assess the mineralogical controls on alkali mobility. 


\section{Regional Geology}

The Abitibi greenstone belt of Québec, in the southeast Superior Province, comprises world-renowned mining localities such as the Val d'Or, Malartic and Rouyn-Noranda gold districts (Fig. 1). Major gold deposits occur principally along a crustal-scale structure, the Cadillac-Larder Lake Fault Zone, which separates the Abitibi greenstone belt to the north from the Pontiac metasedimentary belt to the south. The former consists of a succession of mafic-ultramafic to felsic volcanic rocks of tholeiitic to calc-alkaline affinity (emplaced from 2750 to 2696 Ma; Ayer et al., 2002; Thurston et al., 2008), which was succeeded by greywacke-mudstone sedimentation between 2690 and 2685 Ma (Ayer et al., 2005; Frieman et al., 2017). South of the Cadillac-Larder Lake Fault Zone, the Pontiac Group consists of a turbidite sequence dominated by greywacke-mudstone that were deposited from 2685 to $2682 \mathrm{Ma}$ (Davis, 2002). The Timiskaming Group metasedimentary rocks (alluvial-fluvial facies) were unconformably deposited on older units from 2677 to $2670 \mathrm{Ma}$ (Ayer et al., 2005; Thurston et al., 2008). Several episodes of intrusive magmatism, the onset of which was contemporaneous with early volcanism, continued during to shortly after major tectonic activity (Sutcliffe et al., 1993; Davis et al., 2000; Chown et al., 2002). These intrusions range in composition from sodic tonalite-granodiorite (syn-volcanic), through calc-alkaline tonalite and alkaline syenite (syn-tectonic), to S-type two-mica granite and pegmatite (post-tectonic) (see Gaillard et al. 2018 for further details).

Regional deformation was polyphase, and comprised three main contractional events (Ayer et al., 2002; Robert et al., 2005; Perrouty et al., 2017). The first shortening episode ( $\left.\mathrm{D}_{1}\right)$ initiated immediately after the deposition of the turbidite-dominated basins, and was dominated by a fold-and-thrust style of deformation (Wilkinson et al., 1999; Bleeker, 2015). The second episode of deformation $\left(\mathrm{D}_{2}\right)$ followed deposition of the Timiskaming-type sedimentary rocks, and was manifested by north-south compression and local strike-slip transpression (Daigneault et al., 2002; Robert et al., 2005). This event was broadly contemporaneous with regional metamorphism $\left(\mathrm{M}_{2}\right)$, which ranged in grade from prehnite-pumpellyite to mid-amphibolite facies (Powell et al., 1995). Peak metamorphism was likely reached between 2665 and 2655 Ma, and postdated most $\mathrm{D}_{2}$ deformation (Wilkinson et al., 1999; Ayer et al., 2005; Piette-Lauzière et al., 2018). The third episode of deformation $\left(\mathrm{D}_{3}\right)$ was characterized by dextral transcurrent motion along major fault zones (Daigneault et al., 2002; Ayer et al., 2005). 


\section{Local Geology}

\subsection{Host lithologies}

The Canadian Malartic deposit is hosted by three lithotypes, namely the Pontiac Group metasedimentary rocks, the Piché Group metavolcanic rocks, and porphyritic quartz monzodiorite to granodiorite that intrude these units (Trudel and Sauvé, 1992). The Pontiac Group metasedimentary belt, at the northern margin of the Pontiac subprovince, forms a laterally extensive unit that stretches along the Cadillac-Larder Lake Fault Zone (Camiré et al., 1993; Mortensen and Card, 1993). It is composed of greywacke-mudstone successions, the petrographic and lithogeochemical characteristics of which will be described in detail later in this paper (see sections 6.1 and 6.2). The Piché Group (>2709 Ma; Pilote et al., 2015) forms a thin unit $(<2 \mathrm{~km})$ restricted to the Cadillac-Larder Lake Fault Zone, and consists dominantly of mafic-intermediate to ultramafic metavolcanic rocks, as well as minor mafic to felsic intrusions and metasedimentary rocks (Simard et al., 2013; Bedeaux et al., 2018). In the Malartic district, these units are intruded by a series of quartz monzodiorite to granodiorite porphyritic intrusions that were emplaced at 2677-2679 Ma (Helt et al., 2014; De Souza et al., 2015, 2016).

\subsection{Deformation and metamorphism}

The Malartic district was affected by a complex sequence of deformation and metamorphic events (Camiré and Burg, 1993; Benn et al., 1994; Ghassemi, 1996; Perrouty et al., 2017; Gaillard et al., 2018; Piette-Lauzière et al., 2018). The first episode of compressional deformation $\left(D_{1}\right)$ was manifested by isoclinal folding of the Pontiac Group metaturbidites $\left(\mathrm{F}_{1}\right)$, and is generally recognized from inversions in the polarity of the sedimentary bedding (Perrouty et al., 2017; Gaillard et al., 2018). The second episode of deformation $\left(\mathrm{D}_{2}\right)$ produced moderately tight, upright folds $\left(\mathrm{F}_{2}\right)$ associated with a penetrative axial-planar cleavage $\left(\mathrm{S}_{2}\right)$ (Trudel and Sauvé, 1992). The $\mathrm{S}_{2}$ foliation represents the dominant tectono-metamorphic fabric in the Malartic district (associated with $\mathrm{M}_{2}$ metamorphism), and is defined by biotite \pm white mica and subordinate chlorite, as well as aligned aggregates of pyrite \pm pyrrhotite-chalcopyrite (Gaillard et al., 2018). A third episode of deformation $\left(\mathrm{D}_{3}\right)$ is represented by rare chevron folds $\left(\mathrm{F}_{3}\right)$ and small-scale kink bands, and is locally associated with late chlorite-calcite stringers (Desrochers, 1996; Perrouty et al., 2017).

The $\mathrm{M}_{2}$ metamorphic event is reflected in the Malartic district by a gradual increase in grade from upper greenschist facies (biotite zone) adjacent to the Cadillac-Larder Lake Fault Zone to mid-amphibolite facies 
111 (staurolite zone) a few kilometers (generally 1.5 to 2.5 kilometers) to the south (Fig.2). The axial-planar

112 setting of the metamorphic foliation $\left(\mathrm{S}_{2}\right)$ relative to the $\mathrm{F}_{2}$ folds suggests that prograde metamorphism $\left(\mathrm{M}_{2}\right)$

113 was broadly coeval with $\mathrm{D}_{2}$ deformation (Gaillard et al., 2018). In addition, linear inclusion trails oriented

114 parallel to the $\mathrm{S}_{2}$ foliation in garnet and staurolite are interpreted to reflect a late-kinematic timing for peak 115 metamorphism $\left(\mathrm{M}_{2}\right)$ relative to $\mathrm{D}_{2}$ deformation (Piette-Lauzière, 2017; Gaillard et al., 2018). These textural

116 interpretations are consistent with geochronological evidence from Lu-Hf dating on garnet, which indicate

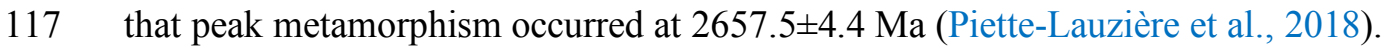

118 4. Canadian Malartic Gold Deposit

119 The Canadian Malartic deposit is a world-class low grade, large tonnage gold deposit that contains reserves estimated at $6.38 \mathrm{Moz} \mathrm{Au}$ at a grade of $1.10 \mathrm{~g} / \mathrm{t} \mathrm{Au}$. The deposit overall gold endowment, calculated

121 from the present and past production, plus mineral reserves and resources (excluding inferred) is estimated 122 at 16.3 Moz Au (see Gaillard et al., 2018 and references therein). With an annual gold production of 0.63 $123 \mathrm{Moz} \mathrm{Au}$ in 2017, the Canadian Malartic open-pit mine is currently the largest gold-producing operation in 124 Canada.

\subsection{Nature and distribution of mineralized zones}

127 semi-continuous halo of pyritic alteration, which generally transitions inwards to higher grade $(>1 \mathrm{~g} / \mathrm{t} \mathrm{Au})$ 128 stockwork and breccia zones (Fig. 3; Robert and Poulsen, 1997). The distribution of the mineralized zones 129 is controlled by three main structures, which are interpreted to have acted as preferential pathways for 130 hydrothermal fluids (Fig. 3). First, the Sladen Fault is a 3 km-long, E-W-trending, S-dipping ductile-brittle 131 shear zone, and represents a first-order splay off the Cadillac-Larder Lake Fault Zone (Fig. 3; Trudel and 132 Sauvé, 1992; De Souza et al., 2016). Second, the NW-SE deformation zones represent a series of parallel, 133 high-strain bands axial-planar to $F_{2}$ folds (Fig. 3; Sansfaçon and Hubert, 1990; De Souza et al., 2016).

134 Third, the Barnat Fault forms of a corridor of anastomosing shears that extend along the southern margin 135 of the Cadillac-Larder Lake Fault Zone, parallel to the NW-SE deformation zones (Fig. 3; Trudel and 136 Sauvé, 1992). Gold mineralization also displays a close spatial association with quartz monzodiorite to 137 granodiorite porphyritic intrusions, most notably along faulted contacts with the metasedimentary and 138 metavolcanic host rocks (Fig. 3; Helt et al., 2014; Perrouty et al., 2017). 


\subsection{Hydrothermal alteration}

The Canadian Malartic deposit is typified by stockworks of quartz-biotite-carbonate-microcline \pm pyrite veinlets (v2) associated with a pervasive microcline-albite-biotite \pm (white mica)-carbonate-pyrite alteration

142 (Robert, 2001; de Souza et al., 2015, 2016; Gaillard et al., 2018). Systematic variations in alteration reflect

143 a lateral zonation of hydrothermal features away from the fluid corridors (de Souza et al., 2016; Gaillard et

144 al., 2018). The proximal alteration is typified by a beige-brown replacement-type assemblage dominated

145 by microcline \pm albite-quartz, with variable proportions of phlogopite, calcite, Fe-dolomite, pyrite and rutile

146 (Fig. 5A-B). This alteration displays a strong genetic association with ore-stage (v2) veinlets, and coincides

147 spatially with dense veining in stockwork and breccia zones (Fig. 5A-B).

148 In the metasedimentary rocks, the proximal alteration transitions outwards to a blue-grey distal alteration 149 assemblage consisting of biotite, microcline \pm albite, phengite, quartz, calcite, pyrite and rutile (Fig. 5C-D).

150 The strength of the distal alteration is controlled mainly by ore-stage (v2) veinlets, as manifested by a broad 151 correlation of pyrite and calcite alterations with veining (v2) intensity (Fig. 5C-D). The transition from 152 proximal to distal alteration is accompanied by a gradual increase in the proportions of biotite (Mg-rich) 153 and white mica (phengite) at the expense of microcline \pm albite (Fig. 5C-D). The mineralogy of the distal 154 assemblage is affected by the composition of the metasedimentary rocks, as indicated by increased phengite 155 alteration in fine-grained mudstone beds (de Souza et al., 2016; Gaillard et al., 2018; Lypaczewski et al., in 156 review) (Fig. 5C).

157 In addition, hydrothermal alteration is also manifested by a broad sulfidation-oxidation halo surrounding 158 the main fluid pathways (Gaillard et al., 2018). This halo is delineated by systematic outward transitions in 159 Fe-sulfide (from pyrite to pyrite \pm pyrrhotite) and Fe-Ti oxide (from rutile to ilmenite) minerals, and typically 160 extends a few meters beyond the limit of the ore-shell $(>0.35 \mathrm{~g} / \mathrm{t} \mathrm{Au})$. These transitions are interpreted to 161 reflect decreases in sulfidation $\left(\sum a \mathrm{~S}\right)$ and oxidation $\left(f \mathrm{O}_{2}\right)$ parameters away from the hydrothermal corridors 162 (Nesbitt, 1986a,b; Gaillard et al., 2018).

\subsection{Ore mineralogy}

164 Gold mineralization at Canadian Malartic consists of native gold and $\mathrm{Au}-(\mathrm{Ag})$-bearing telluride minerals 165 in quartz-biotite-carbonate-microcline \pm pyrite (v2) veinlets and associated alteration envelopes (Helt et al., 166 2014; De Souza et al., 2016; Gaillard et al., 2018). The ore assemblage is typified by native gold, petzite $167\left(\mathrm{Ag}_{3} \mathrm{AuTe}_{2}\right)$ and calaverite $\left(\mathrm{AuTe}_{2}\right)$, along with hessite $\left(\mathrm{Ag}_{2} \mathrm{Te}\right)$, altaite $(\mathrm{PbTe})$ and minor Bi-bearing 
tellurides (Helt et al., 2014). These minerals are generally accompanied by minor chalcopyrite and galena, as well as rare sphalerite and molybdenite. Mineralogical and textural observations indicate a consistent association of native gold and telluride minerals with disseminated pyrite (Helt et al., 2014; Gaillard et al.,

171 in review). This association is generally manifested by the precipitation of gold-bearing minerals in the 172 vicinity, or in direct contact with pyrite grains. Hydrothermal pyrite typically displays composite textures 173 manifested by three main paragenetic stages (Type 1 to 3), the first and second of which are interpreted to 174 have precipitated from ore-forming fluids (Gaillard et al., in review). Native gold and Au-(Ag)-telluride 175 minerals also occur as small (sub-micron) inclusions and nano-particles in Type 1 and 2 pyrite, as indicated 176 by elevated $\mathrm{Au}$ and ore-related element (Ag, Te, $\mathrm{Pb}$ and $\mathrm{Bi}$ ) concentrations (Gao et al., 2015; Gaillard et 177 al., in review).

178 5. Methods

\subsection{Sampling strategy}

A total of 596 metasedimentary rock samples were collected and analyzed for whole-rock major and trace element compositions (see Piercey et al. (2014) for details on the sampling protocol). The drill core

182 and surface samples were taken from homogeneous intervals representative of the lithology and alteration 183 at each site. Sampling was distributed across the Malartic district over an area of approximately $15 \times 7.5$ 184 kilometers, thus providing a regional framework with which to assess the metasomatic effects associated 185 with hydrothermal fluid-rock interaction (Fig. 2). Sampling density was increased near the deposit to assess 186 the lithogeochemical signatures of the proximal and distal alteration facies. The regional distribution of samples was designed to characterize the background geochemical variations of the Pontiac Group

188 metasedimentary rocks. With respect to the latter, samples were divided into three groups according to their 189 alteration characteristics, from background samples $(n=443)$ with no visible evidence of hydrothermal 190 alteration, to distal $(n=123)$ and proximal $(n=30)$ alteration types.

\subsection{Whole-rock lithogeochemical analyses}

192 The samples were crushed, split and pulverized with mild steel to $<75 \mu \mathrm{m}$ (package Prep-31) by ALS 193 Canada (Vancouver, BC). The major and minor element compositions were determined after lithium fusion 194 using wavelength dispersive X-ray fluorescence analysis (package 4C-XRF Fusion) by Activation 195 Laboratories (Ancaster, ON). The minor and trace element compositions, including those of rare earth 
elements (REE), were analyzed using a combination of ICP-AES and -MS after sodium peroxide fusion

197 (package GE ICM90A) by SGS Canada (Burnaby, BC). Whole-rock major, minor and trace element

198 compositions, including gold concentrations, were also determined using ICP-AES and ICP-MS analysis

199 following partial digestion using aqua regia (package ME-MS41L) by ALS Canada. Whole-rock sulfur

200 and carbon analyses were carried out using a LECO analyzer (infrared absorption spectroscopy after

201 combustion) by SGS Canada (package GE CSA06V). The accuracy and precision of the whole-rock

202 lithogeochemical analyses were monitored through systematic incorporation of standard, blank and

203 duplicate samples. Details of the quality control and assurance protocols (QA/QC), and cross-validation

204 results are provided in Perrouty et al. (2018).

205

206

207

208

209

210

211

212

213

214

215

216

217

218

219 220 2014).

221

222

223

224

\subsection{Evaluation and preparation of the lithogeochemical dataset}

A systematic approach was implemented to evaluate the lithogeochemical dataset as a prerequisite for further investigation and statistical analysis. Elements with more than $5 \%$ of values below the lower detection limit (non-detect values) were discarded (left-censored datasets). In addition, elements with a large number of values close to detection limit (i.e., more than $50 \%$ of analyses below $3 \times$ LOD value) were also removed. The presence of non-detect values is typically a source of complication for subsequent data analysis and calculation of summary statistics (Helsel, 2005; Huston and Juarez-Colunga, 2009). Simple methods for handling censored values (deletion or arbitrary replacement) typically disregard the effects of closure that characterize compositional data (Aitchison, 1986) and have been shown to generate biased estimates of the mean and variance (Helsel and Gilliom, 1986; Makvandi et al., 2016). In this study, a multivariate imputation method was implemented to replace the censored values using the zCompositions package in the R software environment (Hron et al., 2010; Palarea-Albaladejo and Martin-Fernández, 2013, 2015). The imputation method relied on the robust isometric log-ratio expectationmaximisation algorithm, an iterative compositional procedure that estimates the non-detect values through the preservation of the multivariate relative covariation structure of the dataset (Palarea-Albaladejo et al.,

\subsection{Mass balance calculations}

Mass transfer associated with hydrothermal alteration was calculated following the principles of Gresens (1967), wherein the evaluation of mass changes is based on the comparison of altered rock compositions with those of their least altered rock equivalents (precursors). In the absence of density measurements, the 
overall mass/volume change caused by hydrothermal alteration was estimated using immobile element

226 ratios (MacLean, 1990). Elements such as $\mathrm{Al}$, $\mathrm{Ti}$ and $\mathrm{Zr}$ are generally considered to be immobile

227 in hydrothermal systems under a wide range of physico-chemical conditions (Finlow-Bates and Stumpfl,

228 1981; MacLean and Barrett, 1993). Because immobile element pairs retain constant ratios during alteration,

229 the selection of immobile elements for mass change calculations can be assessed graphically from their

230 linear relationships in bi-variate plots (MacLean and Kranidiotis, 1987). As shown by Warren et al. (2007),

231 the use of immobile element ratios in place of density and volume factor terms yields a simplified

232 expression of Gresens' mass change equation, which is equivalent to that of MacLean and Barrett (1993).

233 This approach involves the calculation of the reconstructed composition of a component X, corrected for

234 the overall mass/volume change produced by hydrothermal alteration:

$$
\mathrm{RC}_{\mathrm{X}}^{\mathrm{A}}=\mathrm{C}_{\mathrm{X}}^{\mathrm{A}} \times\left(\mathrm{C}_{\mathrm{imm} .}^{\mathrm{P}} / \mathrm{C}_{\mathrm{imm} .}^{\mathrm{A}}\right)
$$

235 where:

- $\mathrm{C}_{\mathrm{X}}^{\mathrm{A}}$ is the concentration of a component $\mathrm{X}$ in $\mathrm{A}$ (altered rock)

$\circ \mathrm{C}_{\mathrm{imm} .}^{\mathrm{P}} / \mathrm{C}_{\mathrm{imm}}^{\mathrm{A}}$. is the concentration ratio of an immobile component in $\mathrm{P}$ (precursor) to A (altered rock)

In this study, the mass changes are expressed relative to the composition of the precursor rock, and correspond to the ratio of the reconstructed composition of component $\mathrm{X}$ in the sample of interest to the concentration of the same component in the precursor rock:

$$
\Delta_{\mathrm{X}}=\mathrm{RC}_{\mathrm{X}}^{\mathrm{A}} / \mathrm{C}_{\mathrm{X}}^{\mathrm{P}}
$$

where:

- $\Delta \mathrm{x}$ is the mass change of a component $\mathrm{X}$, relative to the precursor composition

- $\mathrm{C}_{\mathrm{X}}^{\mathrm{P}}$ is the concentration of a component $\mathrm{X}$ in $\mathrm{P}$ (precursor)

The expression of the mass transfer as a ratio relative to the precursor composition yields results that are restricted to the positive number space, which facilitates data manipulation (e.g., log-transformation) for subsequent statistical calculations and map representation (cf. Perrouty et al., 2018). In this context, the values below unity correspond to depletions, whereas values above unity represent enrichments relative 249 to the least altered samples (e.g., concentration factor). 


\subsection{Lithogeochemical mapping and spatial data analysis}

The results of the mass change calculations are presented as a series of maps that illustrate the 252 distribution of fluid-rock metasomatic interactions in the metasedimentary rocks of the Malartic district. 253 Spatial interpolation between the discrete data points was conducted using a minimum curvature gridding 254 algorithm in the Geosoft Oasis Montaj ${ }^{\circledR}$ software. The complete dataset used to produce the 255 lithogeochemical maps is reported separately in the supplementary material attached to this study.

Because the selected criteria for the spatial representation of the mass changes remain partly arbitrary

257 (e.g., the color scale), a statistical approach was implemented to investigate the magnitude and distribution 258 of the metasomatic haloes. The aim of this method is to establish a statistical framework in order to compare 259 the spatial extent of the different lithogeochemical anomalies, and thus to provide robust constraints on the mobility of the pathfinder elements. Our approach therefore consists in formulating the mass balance results

261 in terms of standard deviation distance relative to the background population mean (standard score). This method is generally referred to as standardization and is most commonly applied to normally-distributed datasets. For most elements, however, the distribution of the mass change data in the background metasedimentary rock population $(\mathrm{n}=443)$ is best approximated by a log-normal distribution. For this

265 reason, the geometric mean $\left(\overline{\mathrm{x}}^{*}\right)$ and multiplicative standard deviation $\left(\mathrm{s}^{*}\right)$ were used to characterize 266 the central tendency and dispersion of the data, respectively (Limpert et al., 2001). Given a component X, 267 these parameters are expressed as:

$$
\begin{aligned}
& \overline{\mathrm{x}}^{*}=\exp \left(\frac{1}{\mathrm{n}} \cdot \sum_{\mathrm{i}=1}^{\mathrm{n}} \ln \left(\mathrm{x}_{\mathrm{i}}\right)\right) \\
& \mathrm{s}^{*}=\exp \left(\sqrt{\frac{1}{\mathrm{n}-1} \cdot \sum_{\mathrm{i}=1}^{\mathrm{n}}\left[\ln \left(\frac{\mathrm{x}_{\mathrm{i}}}{\overline{\mathrm{x}}^{*}}\right)\right]^{2}}\right)
\end{aligned}
$$

268 where:

$269 \quad \mathrm{n}$ represents the number of observations

$270 \quad \circ \mathrm{x}_{\mathrm{i}}$ corresponds to the mass change values $(\Delta \mathrm{x})$ calculated for a component $\mathrm{X}$

271 Accordingly, the geochemical anomalies are evaluated relative to the background compositions using a 272 standardization algorithm that is based upon the multiplicative properties of the log-normal distribution: 


$$
\mathrm{Z}_{\Delta \mathrm{X}}^{*}=\frac{\ln \left(\mathrm{x}_{\mathrm{i}}\right)-\ln \left(\overline{\mathrm{x}}_{\text {background }}^{*}\right)}{\ln \left(\mathrm{s}_{\text {background }}\right)}
$$

where:

○ $Z_{\Delta X}^{*}$ is the standardized mass change value for a component $\mathrm{X}$ relative to the background distribution

$\circ \mathrm{X}_{\mathrm{i}}$ is the mass change values $(\Delta \mathrm{x})$ calculated for a component $\mathrm{X}$

$\bigcirc \overline{\mathrm{x}}_{\text {background }}$ represents the geometric mean of the background population

$\circ \mathrm{s}^{*}{ }_{\text {background }}$ represents the multiplicative standard deviation of the background population

Interpolated maps of the standardized mass change data were produced following the same guidelines as for the raw mass balance data. A unique color scale (class interval representation), based on multiples of the standard deviation distance to the mean value (log-transformed) was used for all the variables.

\section{Pontiac Group Metasedimentary Host Rocks}

\subsection{Petrography of the background metaturbidites}

The Pontiac Group metasedimentary rocks form a flyschoid sequence composed of interstratified beds of mudstone (pelitic) to greywacke (psammitic) (Dimroth et al., 1982; Mortensen and Card; 1993; Ghassemi, 1996). The planar-stratified sedimentary beds range in thickness from a few centimeters up to a meter, and generally display parallel, millimeter-scale internal laminations (Fig. 4a-b). Individual strata commonly display evidence of graded-bedding, as manifested by a progressive upward decrease in detrital grain size (Fig. 4a-b). The clastic particles range in diameter from $<50 \mu \mathrm{m}$ in mudstone, to $2 \mathrm{~mm}$ in greywacke, and reach a maximum of $12 \mathrm{~mm}$ in rare conglomeratic beds (Ghassemi, 1996). The vertical succession of the sedimentary facies is generally consistent with a partial Bouma sequence, which suggests that the Pontiac Group wackes were deposited from turbidity currents (Benn et al., 1994; Card and Poulsen, 1998). This interpretation is further supported by the presence of internal sedimentary structures typical of turbidites including load casts, cross-laminations and flame structures (Goulet, 1978; Ricci-Lucchi and Amorosi, 1978).

The mineralogy of the Pontiac Group metasedimentary rocks varies systematically as a function of the protolith grain size and metamorphic grade. Greenschist facies metaturbidites are composed of quartz, plagioclase and biotite, with lesser but variable proportions of white mica, chlorite, epidote, ilmenite, pyrite, pyrrhotite and magnetite (Fig. 4d-f). Because finer-grained turbidite layers originally contained a greater 
amount of clay minerals, the mudstone facies generally displays higher modal proportions of white mica and biotite compared to the greywacke. Such modal variations are therefore interpreted to reflect changes in bulk-rock compositions caused by primary sedimentary processes (e.g., aluminous nature of pelitic layers). At higher metamorphic grades, variations in protolith composition partly determine the mineralogy of the peak metamorphic assemblage; more specifically, staurolite (and garnet) porphyroblasts form preferentially in fine-grained pelitic beds of the turbiditic sequence (Gaillard et al., 2018; Piette-Lauzière et al., 2018). The metamorphic index minerals therefore provide key indicators to discriminate among the sedimentary facies at higher metamorphic grade (i.e., amphibolite facies), wherein metamorphic recrystallization of quartz and plagioclase typically forms a granoblastic polygonal texture that obliterates the primary sedimentary textures (Ghassemi, 1996).

\subsection{Lithogeochemistry of the background metaturbidites}

The variations in protolith grain size are manifested by consistent changes in bulk-rock lithogeochemical 311 compositions. Such variations are interpreted to reflect predominantly the effects of physical sorting (grain 312 size and density) during transport and deposition of the clastic sediments (Fig. 4). Therefore, in order to 313 evaluate the effects of the sedimentary processes on lithogeochemical variability (Cai et al., 2008; Mishra 314 and Sen, 2011), the metasedimentary rocks were separated into four sub-lithologies according to textural 315 (grain size) and mineralogical characteristics, namely, greywacke $(\mathrm{n}=247)$, siltstone $(\mathrm{n}=134)$ and mudstone $316(\mathrm{n}=188)$, as well as a group defined by lower $\sum$ REE concentrations $(\mathrm{n}=27)$ and a distinct chondrite317 normalized REE profile. The variations in whole-rock major element concentrations among the sub318 lithologies in the background metasedimentary rocks are illustrated in Figure 6 using box and whisker 319 diagrams (additional plots for minor and trace elements are provided in Appendix 1).

320 The greywacke (coarse-grained) fraction of the metasedimentary rocks is generally characterized by 321 higher concentrations of $\mathrm{SiO}_{2}$ (average $66.1 \mathrm{wt} . \%$ in the background population) relative to the siltstone $322(65.0 \mathrm{wt} \%)$ and mudstone (60.9 wt\%) fractions (Fig. 6). In addition, greywacke also displays elevated 323 concentrations of $\mathrm{Na}_{2} \mathrm{O}(3.73 \mathrm{wt} \%)$ and $\mathrm{CaO}(2.59 \mathrm{wt} \%)$ compared to siltstone (3.64 and $2.48 \mathrm{wt} \%$, respectively) and mudstone (2.96 and $2.10 \mathrm{wt} \%$, respectively) (Fig. 6). These variations are interpreted to 325 reflect higher modal proportions of quartz and plagioclase in the coarse-grained sediments (Fig. 4). In 326 contrast, the mudstone (fine-grained) fraction has higher average concentrations of $\mathrm{Al}_{2} \mathrm{O}_{3}(17.7 \mathrm{wt} \%)$ relative to siltstone $(15.7 \mathrm{wt} \%)$ and greywacke $(15.3 \mathrm{wt} \%)$. In addition, increases in the concentrations of 
329 (from 0.54 to $0.67 \mathrm{wt} \%$ ) are also associated with decreasing grain size, from greywacke to mudstone (Fig.

330 6). These trends are interpreted to be mainly controlled by increasing proportions of hydrous phyllosilicates 331 (dominantly biotite and white mica) in the fine-grained sediment fractions, and likely correspond to elevated 332 proportions of clays in the protolith (Camiré et al., 1993; Fig. 4). This interpretation is supported by a 333 general increase in loss on ignition (LOI), from $1.25 \mathrm{wt} \%$ in greywacke, to $1.98 \mathrm{wt} \%$ in mudstone (Fig. 6).

334 These trends also coincide with a progressive increase in the average concentrations of most minor elements 335 (e.g., $\mathrm{Ba}, \mathrm{Cr}, \mathrm{V}, \mathrm{Rb}, \mathrm{Ni}, \mathrm{Co}, \mathrm{Ga}$ ) with decreasing grain size, except for antithetic decreasing trends in $\mathrm{Sr}$ 336 and $\mathrm{Zr}$ concentrations (Appendix 1). The minor element enrichments documented in the fine-grained 337 fractions are interpreted to be controlled by greater proportions of phyllosilicates (biotite \pm white mica) and 338 subordinate oxide phases (ilmenite \pm magnetite), whereas opposite trends (i.e., towards the greywacke 339 fraction) are likely attributable to dilution by quartz and plagioclase (Cai et al., 2008; Mishra and Sen, 340 2011). The low $\sum R E E$ group of metasedimentary rocks has major (Fig. 6) and minor (Appendix 1) element 341 compositions that are intermediate between those of siltstone and mudstone. However, the low $\sum \mathrm{REE}$ 342 sediments are consistently depleted in REE (Fig. 7) and display lower abundances of Ni and Co compared 343 to the other sub-lithologies (Appendix 1).

344 Despite the variability in protolith compositions inherent to primary sedimentary processes, the linear 345 variations documented for Pontiac Group metaturbidites on immobile-immobile bivariate diagrams define 346 a lithogeochemically consistent metasedimentary sequence (Helt et al. 2014). Specifically, the positive 347 correlation between $\mathrm{Al}_{2} \mathrm{O}_{3}$ and $\mathrm{TiO}_{2}(\mathrm{r}=0.78)$ suggests a strong cogenetic relationship across the 348 stratigraphic sequence (Fig. 7a). The geochemical signatures of the metaturbidites were further assessed by 349 comparing REE patterns normalized to chondrite composition (Fig. 7b). Aside from a limited number of 350 samples characterized by a distinct signature and a low total $\sum R E E$ content $(n=27)$, the resulting profiles 351 are nearly identical and differ mainly in the absolute REE concentrations $(n=569)$. These similarities 352 suggest that the Pontiac Group metaturbidites likely had a single provenance (Camiré et al., 1993), although 353 the low $\sum$ REE population may reflect intermittent (and minor) contribution of clastic material from a source 354 (Fig. 7b). 


\section{Mass Transfer in Hydrothermally Altered Metasedimentary Rocks}

The mass changes associated with hydrothermal alteration in the metasedimentary rocks characterize the lithogeochemical signature of the Canadian Malartic deposit, and can be used to develop parameters for mapping the intensity and distribution of fluid-rock interactions at the district scale. However, as noted above, the evaluation of mass transfer in sedimentary rocks is often hampered by geochemical variability in protolith compositions (Fig. 6; Appendix 1). To reduce the effects of such variations on the mass transfer calculations, the metasedimentary rocks were divided into four sub-lithologies according to grain size and REE signatures (Figs. 6-7). In the Malartic district, the background populations of the greywacke, siltstone, mudstone and low $\sum$ REE sediments display relatively narrow compositional ranges (Fig. 6; Appendix 1). The primary variations in each sub-lithology are therefore interpreted to be negligible compared with those of the sedimentary sequence as a whole, thereby providing an appropriate rock classification to quantify alteration-related mass transfer.

\subsection{Least altered samples}

A set of least altered samples ( $\mathrm{n}=20)$ was selected from the Pontiac Group metasedimentary host rocks based on petrographic (textural and mineralogical features) and lithogeochemical characteristics. Average least altered compositions were calculated separately for each of the sub-lithologies from representative samples of greywacke $(n=6)$, siltstone $(n=4)$, mudstone $(n=6)$, and low $\sum R E E(n=4)$ metasedimentary rocks.

The least altered samples were carefully inspected to avoid any signs of hydrothermal alteration or surficial weathering. Because gold mineralization is typically associated with disseminated pyrite and carbonate (calcite $\pm \mathrm{Fe}$-dolomite) alteration, the criteria for the selection of the least altered samples included low concentrations of $\mathrm{Au}(<5 \mathrm{ppb}), \mathrm{S}(<0.3 \mathrm{wt} \%)$ and $\mathrm{C}(<0.3 \mathrm{wt} \%)$. The distance to the ore shell was also taken into consideration, so that the least altered samples were derived from drill core and outcrops located $>1.5$ kilometers from to the Canadian Malartic deposit.

\subsection{Immobile elements}

The overall effects of mass/volume changes caused by hydrothermal alteration were evaluated by normalizing the compositions of the altered samples to those of their respective precursors using immobile element ratios (MacLean and Kranidiotis, 1987). Element immobility was tested using bi-variate plots, in which immobile elements define linear arrays that pass through the origin (MacLean, 1990). The bulk-rock 
concentrations of $\mathrm{Al}_{2} \mathrm{O}_{3}$ and $\mathrm{TiO}_{2}$ were shown to delineate the best linear trend $(\mathrm{r}=0.78$; Fig. $7 \mathrm{a})$, thereby indicating that these elements remained essentially immobile during alteration (MacLean and Barrett, 1993; Helt et al., 2014). For this reason, immobile element ratios calculated from $\mathrm{Al}_{2} \mathrm{O}_{3}$ concentrations were used to assess the mass transfer associated with alteration.

\subsection{Mass transfer associated with hydrothermal alteration}

Average mass changes were determined for proximal and distal alteration assemblages to evaluate the metasomatic effects associated with ore-forming processes, and to identify potential pathfinder elements that could be used as vectors to gold mineralization. The results are presented as a series of box and whisker diagrams in Figures 8-9 and Appendix 2 for the distal $(n=123)$ and proximal $(n=30)$ alteration zones, and are evaluated relative to the background metasedimentary rock population $(n=443)$. Comparison of the average compositions of altered and least-altered rocks $(n=20)$ indicates a significant increase in the concentrations of $\mathrm{Au}-\mathrm{Te}-\mathrm{W}-\mathrm{Ag} \pm\left(\mathrm{As}-\mathrm{Be}-\mathrm{Sb}-\mathrm{Bi}-\mathrm{Mo}-\mathrm{Pb}\right.$ ) as well as $\mathrm{C}-\mathrm{S}-\mathrm{K}_{2} \mathrm{O}$ and $\mathrm{LOI}$ in the rocks associated with gold mineralization (Figs. 8-9).

The results of mass transfer calculations define systematic enrichments from background compositions, through distal to proximal alteration zones. The proximal and distal alteration assemblages are characterized by substantial gains in $\mathrm{C}$ (mean $\Delta_{\mathrm{C}}=56.2$ and 21.0, respectively), $\mathrm{S}\left(\Delta_{\mathrm{S}}=18.4\right.$ and 4.8$), \mathrm{K}\left(\Delta_{\mathrm{K} 2 \mathrm{O}}=2.6\right.$ and 1.7) and LOI $\left(\Delta_{\mathrm{LOI}}=6.3\right.$ and 3.0), compared to least-altered equivalents (Fig. 8). These observations are consistent with mineralogical characteristics of the alteration assemblages, and correlate with increasing modal proportions of calcite $\pm \mathrm{Fe}$-dolomite and pyrite with increasing proximity to the hydrothermal fluid pathways (Fig. 5; De Souza et al., 2016; Gaillard et al., 2018). Potassium addition in hydrothermally-altered rocks is interpreted to reflect the effects of microcline and biotite \pm white mica alteration (Fig. 5; Helt et al., 2014; Gaillard et al., 2018). Small, but significant gains in $\mathrm{Na}\left(\Delta_{\mathrm{Na} 2 \mathrm{O}}=1.37\right.$ and 1.06 in proximal and distal alteration zones, respectively) and $\mathrm{Ca}\left(\Delta_{\mathrm{CaO}}=1.48\right.$ and 1.13) are restricted mainly to the proximal alteration assemblage, and are associated with pervasive feldspathization (microcline \pm albite) and carbonate alteration (Fig. 8). Other major elements, including $\mathrm{Si}\left(\Delta_{\mathrm{SiO} 2}=0.99\right.$ in altered rocks $), \operatorname{Mg}\left(\Delta_{\mathrm{MgO}}=1.06\right), \operatorname{Ti}\left(\Delta_{\mathrm{TiO} 2}=\right.$ 1.09) and $\mathrm{Fe}\left(\Delta_{\mathrm{Fe} 2 \mathrm{O} 3}=1.11\right)$ display only limited mass changes related to fluid-rock interaction, and are relatively constant in the different alteration zones (Appendix 2).

Gold mineralization in the proximal and distal alteration zones is associated with major gains in $\mathrm{Au}$ ( $\Delta_{\mathrm{Au}}$ of 1968 and 586, respectively), along with substantial enrichments in $\mathrm{Te}\left(\Delta_{\mathrm{Te}}\right.$ of 146.2 and 21.5), 
$412 \mathrm{~W}\left(\Delta_{\mathrm{W}}\right.$ of 65.8 and 17.1), $\mathrm{Ag}\left(\Delta_{\mathrm{Ag}}\right.$ of 41.7 and 6.8$), \mathrm{As}\left(\Delta_{\mathrm{As}}\right.$ of 16.8 and 13.8$), \mathrm{Be}\left(\Delta_{\mathrm{Be}}\right.$ of 8.4 and 3.8),

$413 \mathrm{Sb}\left(\Delta_{\mathrm{Sb}}\right.$ of 5.3 and 3.3), $\mathrm{Bi}\left(\Delta_{\mathrm{Bi}}\right.$ of 7.4 and 2.3), Mo ( $\Delta_{\mathrm{Mo}}$ of 13.8 and 2.2$)$ and $\mathrm{Pb}\left(\Delta_{\mathrm{Pb}}\right.$ of 6.3 and 2.5$)$

414 relative to least-altered equivalents (Fig. 9). These enrichments are consistent with the mineralogy of the 415 ore assemblage, and thus define the metallic signature of the deposit (Helt et al., 2014; Gaillard et al., 2015;

416 De Souza et al., 2015, 2016). Substantial mass gains documented for $\mathrm{Au}, \mathrm{Te}, \mathrm{Ag}, \mathrm{Pb}$ and $\mathrm{Bi}$ in the

417 mineralized samples reflect the presence of native gold and $\mathrm{Au}-\mathrm{Ag}-(\mathrm{Pb}-\mathrm{Bi})$-bearing telluride minerals such

418 as petzite, hessite, altaite and calaverite (Gaillard et al., in review). By contrast, bulk-rock enrichments in

$419 \mathrm{~W}$ and $\mathrm{Sb}$ in the altered rocks are attributed predominantly to the precipitation of rutile, which tends to be 420 anomalous in these elements at Canadian Malartic (Clark et al., in prep.).

\subsection{Correlation relationships among mass change values}

The mineralogical controls on the metasomatic processes associated with ore-forming processes were evaluated from the correlation relationships among mass change values (Fig. 10). Given the relative nature of the mass transfer calculations (i.e., normalization to a precursor composition), such correlations are essentially unaffected by the effects of closure that generally affect compositional data (Aitchison, 1986). In addition, these correlation relationships are less influenced by primary depositional features compared to raw lithogeochemical data, and thus provide insights into the mechanisms that govern metasomatic reactions and metal distribution (Libbey and Williams-Jones, 2016).

The linear correlation $(\mathrm{r}=0.66)$ between $\Delta_{\mathrm{Au}}$ and $\Delta_{\mathrm{S}}$ mass changes reflects a close spatial and genetic relationship between gold mineralization and sulfide minerals (Fig. 10). Gold mass change values $\left(\Delta_{\mathrm{Au}}\right)$ also correlate positively with $\Delta_{\mathrm{Te}}(0.66)$ and $\Delta_{\mathrm{Ag}}(0.62)$, thus suggesting similar modes of transport and precipitation for $\mathrm{Au}, \mathrm{Ag}$ and $\mathrm{Te}$ (Fig. 10). These interpretations are further supported by petrographic observations, most notably by the association of native gold and $(\mathrm{Au} \pm \mathrm{Ag})$-telluride minerals in inclusions and fracture-fillings in hydrothermal pyrite (Gaillard et al., in review). For these reasons, gold deposition has been interpreted to result from the destabilization of gold-bisulfide complexes in response to wall-rock sulfidation (Helt et al., 2014). In addition, gold mass change values correlate positively with those of other associated metals, including $\Delta_{\mathrm{W}}(0.66), \Delta_{\mathrm{Be}}(0.58)$ and $\Delta_{\mathrm{Bi}}(0.48)$ (Fig. 10). Because the enrichment factors calculated for such trace elements are log-normally distributed, the correlation relationships among these variables are however best characterized from log-transformed values (Appendix 2). Most significantly, the correlation relationships among log-transformed values define a strong association for $\Delta_{\mathrm{Au}}$ with $\Delta_{\mathrm{Ag}}(0.82)$, 
$\Delta_{\mathrm{Te}}(0.80), \Delta_{\mathrm{W}}(0.78), \Delta_{\mathrm{Be}}(0.70), \Delta_{\mathrm{As}}(0.54), \Delta_{\mathrm{Bi}}(0.53)$ and $\Delta_{\mathrm{Pb}}(0.50)$. Consequently, as discussed below, these metals are likely to have utility as pathfinder elements to identify areas affected by alteration, and to delineate vectors toward ore zones in the Malartic district (cf. Eilu and Mikucki, 1998; Eilu et al., 2001).

Because major element data reflect the primary rock-forming minerals in the host metasedimentary rocks, mass transfer associated with hydrothermal alteration for these components typically defines lower magnitude changes compared to the trace elements. For this reason, the correlation coefficients for major element mass changes are generally lower than those of the pathfinder metals (Fig. 10). Nonetheless, major element mass changes directly reflect the effects of fluid-rock interaction on alteration mineralogy, and thus provide important information with which to evaluate the magnitude of metasomatic reactions adjacent to hydrothermal fluid pathways (Eilu and Groves, 2001; Whitbread and Moore, 2004). The data indicate that there is a strong colinear relationship between $\Delta_{\mathrm{LOI}}$ and $\Delta_{\mathrm{C}}$ mass changes $(\mathrm{r}=0.84)$, as well as weaker positive correlations between $\Delta_{\mathrm{CaO}}$ and $\Delta_{\mathrm{C}}(\mathrm{r}=0.51)$ and $\Delta_{\mathrm{CaO}}$ and $\Delta_{\mathrm{LOI}}(\mathrm{r}=0.40)$; these are interpreted to be the result of carbonate alteration (Fig. 10). High correlation coefficients between $\Delta_{\text {LOI }}$ and $\Delta_{\mathrm{S}}(\mathrm{r}=0.75)$, and between $\Delta_{\mathrm{C}}$ and $\Delta_{\mathrm{S}}(\mathrm{r}=0.64)$ further indicate a strong coupling of carbonate (calcite $\pm \mathrm{Fe}$-dolomite) and sulfide (pyrite) alteration. Host-rock sulfidation was also accompanied by pervasive alkali metasomatism $\left(\mathrm{K}_{2} \mathrm{O}\right.$ and $\left.\mathrm{Na}_{2} \mathrm{O}\right)$, as demonstrated by a strong positive correlation relationship between $\Delta_{\mathrm{K}+\mathrm{Na}}$ and $\Delta_{\mathrm{S}}$ mass changes $(\mathrm{r}=0.72)$. The above notwithstanding, $\Delta_{\mathrm{K}}$ displays a weak negative correlation with $\Delta_{\mathrm{Na}}(\mathrm{r}=-0.29)$, which suggests complex mineralogical and physico-chemical controls on potassic-sodic alteration in zones of pervasive microcline \pm albite replacement (Mathieu, 2018; see below).

\section{Molar Element Ratios}

The mineralogical reactions that controlled the mass transfer processes during hydrothermal fluid-rock interaction were evaluated using molar element ratios (Madeisky and Stanley, 1993; Eilu and Groves, 2001; Whitbread and Moore, 2004; Prendergast, 2007; Stanley, 2017). This approach is particularly well-suited to the analysis of metasomatic processes, as molar proportions provide a direct means to correlate changes in bulk-rock lithogeochemistry to alteration mineralogy (Madeisky and Stanley, 1993; Warren et al., 2007). Because they are expressed relative to a conserved component, Pearce element ratios are not affected by closure, and can be used to quantify the lithogeochemical and mineralogical variations associated with hydrothermal alteration (Pearce, 1968; Madeisky and Stanley, 1993). Binary plots based on alkali/aluminium molar ratios $(\mathrm{Na} / \mathrm{Al} v s . \mathrm{K} / \mathrm{Al})$ are presented in Figure 11, and illustrate the mineralogical 
controls on alkali mobility in metasedimentary rocks of the Malartic district (Davies and Whitehead, 2006).

471 Specific nodes in such binary plots represent stoichiometric proportions of common alteration minerals, 472 including feldspars (microcline, albite and plagioclase) and phyllosilicates (biotite, muscovite and chlorite)

473 (Fig. 11; Madeisky and Stanley, 1993; Warren et al., 2007). However, molar element ratio binary plots only 474 capture a partial representation of the system complexity, thereby limiting the evaluation of mass transfer 475 processes to the projected mineral phases.

476 Two versions of the same molar element ratio binary plot $(\mathrm{Na} / \mathrm{Al}$ vs. $\mathrm{K} / \mathrm{Al})$ are presented in Figure 11. 477 In the first, the metasedimentary rocks are color-coded based on petrographical characteristics (grain size) 478 to illustrate the effects of depositional processes on whole-rock composition (Fig. 11A). Most background 479 metasedimentary rocks at Malartic fall within the field outlined by the minerals typical of the metamorphic 480 assemblage, namely biotite, white mica and plagioclase (Fig. 11A). Increasing grain size from mudstone to 481 greywacke shows a general trend toward higher $\mathrm{Na} / \mathrm{Al}$ and lower $\mathrm{K} / \mathrm{Al}$ values (Fig. 11A). These variations are interpreted to reflect progressive mineralogical changes with increasing grain size, as manifested by a trend toward the plagioclase stoichiometric node (i.e., away from biotite and white mica) (Fig. 11A). These results suggest that variations in protolith composition caused by the primary sedimentary processes exert a strong control on the mineralogy of the background metamorphic assemblage.

Metasomatic effects associated with ore-forming processes were evaluated by dividing metasedimentary rocks according to hydrothermal alteration characteristics (Fig. 11B). Mass transfer processes in altered rocks are manifested by a general increase in $\mathrm{K} / \mathrm{Al}$ and/or $\mathrm{Na} / \mathrm{Al}$ ratios relative to background compositions.

489 These variations delineate a broad gradient from background through distal to proximal alteration facies, 490 which is interpreted to reflect progressive changes in mineralogy (and mineral chemistry) in response to 491 increasing alteration intensity (Fig. 11B). The metasedimentary rocks that underwent distal alteration 492 typically fall within a field delimited by biotite, white mica and albite, and partially overlap background 493 compositions. By contrast, the metasedimentary rocks from the proximal alteration zone are characterized 494 by elevated $\mathrm{K} / \mathrm{Al}$ ratios, and fall within a narrow compositional field bounded by biotite, microcline and 495 albite (Fig. 11B). These results suggest that increasing alkali (K-Na) metasomatism from distal to proximal 496 alteration zones was controlled by the increasing stabilities of microcline and albite (at the expense of biotite 497 and white mica), in agreement with petrographic observations. Molar element ratios therefore provide a 
powerful means with which to evaluate the distribution of alteration minerals in the footprint of major hydrothermal systems.

\section{Spatial Distribution of Hydrothermal Fluid-Rock Interactions}

The results of mass transfer calculations were used to assess the magnitude and spatial distribution of metasomatic processes in the metasedimentary rocks of the Malartic district. A compilation of geochemical maps is presented in Figure 12 to illustrate the distribution of mass changes for selected major (alkali and volatile) and pathfinder components. For this purpose, the mass transfer data for each component were first transformed using a Z-score standardization algorithm $\left(\mathrm{Z}_{\Delta \mathrm{X}}^{*}\right)$, and expressed in units of multiplicative standard deviation $\left(\mathrm{s}^{*}\right)$ relative to the geometric mean $\left(\overline{\mathrm{x}}^{*}\right)$ of the background distribution (see section 5.5). This approach facilitates the direct comparison of the metasomatic haloes (spatial extent and magnitude).

The spatial distribution of the gold mass changes $\left(\Delta_{\mathrm{Au}}\right)$ delineates a broad envelope of elevated values centered on the Canadian Malartic deposit (Fig. 12A). As expected, the strongest gold enrichment occurs in the deposit area, and generally corresponds to values exceeding the background average composition by more than two multiplicative standard deviations (i.e., $\mathrm{Z}_{\Delta \mathrm{Au}}^{*}>2$ ) (Fig. 12A). Specifically, samples collected from the open-pit $(n=170)$ have an average $Z_{\Delta A u}^{*}$ value of 3.2, which corresponds to an average enrichment factor $\left(\Delta_{\mathrm{Au}}\right)$ of 690 relative to the least-altered samples. The distribution of high $\mathrm{Z}_{\Delta \mathrm{Au}}^{*}$ values $\left(\right.$ i.e., $\left.\mathrm{Z}_{\Delta \mathrm{Au}}^{*}>1\right)$ extends beyond the limits of the deposit and defines a semi-continuous halo oriented parallel to the $\mathrm{S}_{2}$ foliation. Significantly, the anomalous areas defined by Au mass gains include, in addition to the deposit itself, the main hydrothermal centers and prospects in the district, including the Cartier, Radium, Alpha and Bravo zones (Fig. 12A).

The geochemical anomalies defined by pathfinder trace elements associated with gold mineralization are shown in Figure 12 B to G. Notably, the spatial distributions of mass change values for Te, W, and Ag delineate district-scale alteration footprints around the Canadian Malartic deposit (Fig. 12B-D). The mass gains calculated for these elements are typically the highest within the open-pit area, and decrease with distance away from the deposit (Fig. 12B-D). The Te, W and Ag anomalies contrast markedly with the background compositions; samples from the open-pit $(n=170)$ display pronounced mass gains compared to background metasedimentary rocks, with average $\mathrm{Z}_{\Delta \mathrm{Te}}^{*}, \mathrm{Z}_{\Delta \mathrm{W}}^{*}$ and $\mathrm{Z}_{\Delta \mathrm{Ag}}^{*}$ values reaching 2.9, 2.3 and 2.7, respectively (Fig. 12B-D). Such levels correspond to average $\Delta_{\mathrm{Te}}, \Delta_{\mathrm{W}}$ and $\Delta_{\mathrm{Ag}}$ enrichment factors of 35.8, 
23.4 and 10.6, respectively. The mass gain patterns for these elements define semi-continuous alteration envelopes surrounding the deposit, and extend along strike for $>10$ kilometers (Fig. 12B-D). The geochemical anomalies delineated by Te, $\mathrm{W}$ and $\mathrm{Ag}$ correspond closely to the dispersion halo outlined by the gold mass gains. Because it is not affected by false positive anomalies related to outliers, W (and to a lesser extent Ag) displays the most consistent pathfinder footprint across the district (Fig. 12B-D).

The distributions of mass change values for As $\left(\Delta_{\mathrm{As}}\right)$, $\mathrm{Be}\left(\Delta_{\mathrm{Be}}\right), \mathrm{Sb}\left(\Delta_{\mathrm{Sb}}\right)$ and $\mathrm{Pb}\left(\Delta_{\mathrm{Pb}}\right)$ also define anomalies related to gold mineralization (Fig. 12E-H). Arsenic and Sb display moderate enrichments in the immediate deposit area compared to the least-altered equivalents, and correspond to average $\mathrm{Z}_{\Delta \mathrm{As}}^{*}$ and $\mathrm{Z}_{\Delta \mathrm{Sb}}^{*}$ values of 0.9 and 0.8 , respectively $(n=170)$. These elements delineate anomalies that extend towards the southeast in the direction of the Bravo zone $\left(\mathrm{Z}_{\Delta \mathrm{As}}^{*}\right.$ and $\left.\mathrm{Z}_{\Delta \mathrm{Sb}}^{*}>1\right)$ (Fig. 12E,G). The distribution of Be mass change values $\left(\Delta_{\mathrm{Be}}\right)$ outlines a geochemical zoning with respect to the deposit, which is however partially masked by a number of false anomalies to the south and west of the district (Fig. 12F). Although the highest $\mathrm{Pb}$ enrichment factors $\left(\Delta_{\mathrm{Pb}}\right)$ occur within, and adjacent to the deposit, the distribution of $\mathrm{Pb}$ mass change values is relatively erratic across the district (Fig. 12H).

The spatial distribution of mass change values for mobile alkali and volatile components such as $\mathrm{C}, \mathrm{S}$, $\mathrm{K}_{2} \mathrm{O}$ and LOI is presented in Figure 12 I-L. Significantly, C and $\mathrm{S}$ display strong enrichments in the deposit area, as shown by average $Z_{\Delta C}^{*}$ and $Z_{\Delta S}^{*}$ open-pit values of 1.6 and 1.4 , respectively $(n=170)$. These mass gains also delineate a broad $\mathrm{S}_{2}$-parallel halo beyond the deposit, which is characterized by local enrichments $\left(\mathrm{Z}_{\Delta \mathrm{C}}^{*}\right.$ and $\left.\mathrm{Z}_{\Delta \mathrm{S}}^{*}>1\right)$ that coincide with the locations of other gold prospects in the district (e.g., the Cartier, Radium, Alpha and Bravo zones) (Fig. 12I-J). The distribution of $\mathrm{K}_{2} \mathrm{O}$ mass change values delineates a lithogeochemical anomaly that is mainly restricted to the hydrothermally-altered rocks in the deposit area (Fig. 12K). Despite a relatively limited spatial extent, the potassium alteration halo displays a sharp contrast with background metasedimentary rocks, as reflected by elevated values of $Z_{\Delta \mathrm{K} 2 \mathrm{O}}^{*}(1.2)$ for samples from within the open-pit (Fig. 12K). The few $\mathrm{K}_{2} \mathrm{O}$ anomalies $\left(\mathrm{Z}_{\Delta \mathrm{K} 2 \mathrm{O}}^{*}>1\right)$ outside of the deposit correspond to weakly mineralized hydrothermal centers (e.g., Cartier, Radium, Alpha and Bravo zones) The mass change values for LOI also define a laterally extensive anomaly that extends parallel to the $\mathrm{S}_{2}$ foliation along the Cadillac-Larder Lake Fault Zone (Fig. 12L). This anomaly is interpreted to be controlled predominantly by the combined effects of carbonate and sulfide alteration, as reflected by broad similarities in the mass change distribution patterns for these variables (Fig. 12I-J,L). 


\section{Discussion}

\subsection{Mineralogical controls on hydrothermal alteration}

Lithogeochemical data provide a means of evaluating mineralogical controls on hydrothermal alteration.

558

559

560

561

562

563

564

565

566

567

568

569

570

571

572

573

574

575

576

577

578

579

580

581

582

583

584

In principle, this information can be used to identify the mineralogical changes that define the zonation of alteration features around the Canadian Malartic gold deposit. Most notably, molar element ratio analysis (alkali/aluminium) indicates a progressive decrease in alkali alteration ( $\mathrm{K}$ and $\mathrm{Na}$ ) away from the main hydrothermal fluid pathways (i.e., decreasing gradients of $\mathrm{K} / \mathrm{Al}$ and $\mathrm{Na} / \mathrm{Al}$ ratios) (Fig.11). These results reflect the transition from proximal microcline \pm albite-(phlogopite) to distal biotite \pm phengite-microclinealbite alteration assemblages. The stabilization of microcline at the expense of white mica in the proximal alteration assemblage is consistent with an increase in potassium metasomatism towards the fluid corridors, and can be described by the following reaction:

$\mathrm{KAl}_{3} \mathrm{Si}_{3} \mathrm{O}_{10}(\mathrm{OH})_{2}+6 \mathrm{SiO}_{2}+2 \mathrm{~K}^{+}=3 \mathrm{KAlSi}_{3} \mathrm{O}_{8}+2 \mathrm{H}^{+}$

white mica

microcline

Hydrothermal alteration is further characterized by the progressive increase in sulfur metasomatism adjacent to the fluid pathways. Significantly, the correlation $(r=0.56)$ between $\Delta_{\mathrm{S}}$ and $\Delta_{\mathrm{K}}$ mass changes is interpreted to reflect the mineralogical coupling between sulfidation and potassic alteration. In fact, the increase in pyrite alteration proximal to the fluid corridors is accompanied by an increase in microcline at the general expense of biotite, thereby suggesting the following reaction:

$\mathrm{KFe}_{3} \mathrm{AlSi}_{3} \mathrm{O}_{10}(\mathrm{OH})_{2}+6 \mathrm{H}_{2} \mathrm{~S}+1.5 \mathrm{O}_{2}=\mathrm{KAlSi}_{3} \mathrm{O}_{8}+3 \mathrm{FeS}_{2}+7 \mathrm{H}_{2} \mathrm{O}$

biotite

microcline pyrite

In addition to sulfidation, hydrothermal alteration in the metasedimentary rocks is characterized by the progressive replacement of host-rock plagioclase (oligoclase) by albite and microcline. Because Ca was only weakly enriched during alteration $\left(\Delta_{\mathrm{Ca}}=1.20\right.$ in altered rocks), it is inferred that $\mathrm{Ca}$ in carbonates (calcite and Fe-dolomite) was sourced predominantly from plagioclase breakdown to albite (or microcline), as described by the following reaction:

$$
\begin{aligned}
& \mathrm{Na} 0.72 \mathrm{Ca} 0.27 \mathrm{Si}_{2.74} \mathrm{Al}_{1.26} \mathrm{O}_{8}+0.54 \mathrm{Na}^{+}+1.04 \mathrm{SiO}_{2}+0.27 \mathrm{CO}_{2}+0.27 \mathrm{H}_{2} \mathrm{O}=1.26 \mathrm{NaAlSi}_{3} \mathrm{O}_{8}+0.27 \mathrm{CaCO}_{3}+0.54 \mathrm{H}^{+} \\
& \text {Plagioclase } \\
& \text { quartz } \\
& \text { albite } \\
& \text { calcite }
\end{aligned}
$$

This association between alkali alteration $(\mathrm{K}$ and $\mathrm{Na})$ and carbonatization is reflected by the correlation between $\Delta_{\mathrm{C}}$ and $\Delta_{\mathrm{K}+\mathrm{Na}}$ mass changes $(\mathrm{r}=0.56)$ (Fig. 10). Weak enrichments in $\mathrm{Na}\left(\Delta_{\mathrm{Na}}=1.12\right.$ in altered rocks), however, suggest that some of the Na involved in albitization was locally derived, and may have been 
released during replacement of plagioclase by microcline (Helt et al., 2014; Gaillard et al., 2018). These observations suggest a significant control on the nature of the alteration assemblage by host-rock compositions. As such, alkali metasomatism was likely limited by Al contents, as K- and Na-bearing phases in the alteration assemblage are characterized by alkali/aluminium molar element ratios $\leq 1$ (Mathieu, 2018).

The above reactions $(6,7$ and 8$)$ are consistent with a progressive increase in $f \mathrm{O}_{2}, \sum a \mathrm{~S}$ and $\mathrm{pH}$ conditions with increasing degrees of hydrothermal fluid-rock interaction. The mineralogical reactions that control alkali metasomatism therefore contribute to the delineation of a sulfidation-oxidation halo around the fluid pathways, in agreement with the conclusions of Gaillard et al. (2018). Such mineralogical transitions also support a potassium- and sulfur-rich, oxidized composition for the ore-forming fluids.

\subsection{Controls on the distribution of the metasomatic processes}

The results of mass change calculations were examined to determine the distribution of hydrothermal fluid-rock interaction in the Malartic district (Fig.12). This information was used to outline the patterns and maximum extent of the metasomatic haloes associated with ore-forming processes. The lithogeochemical anomalies display large variations in size and magnitude among the variables, which were affected by the composition of the mineralizing fluids, and differences in the mobility and reactivity of alteration-related elements. The above notwithstanding, most alteration haloes have similar geometries, and define elongate envelopes that extend parallel to the main $\left(\mathrm{S}_{2}\right)$ foliation (Fig.12).

The distribution of mass transfer processes depends on several criteria, foremost among which are the structural features that controlled the circulation of the mineralizing fluids. At Canadian Malartic, the main ore-stage is interpreted to have been synchronous with the $\mathrm{D}_{2}$ deformation event, and the ore zones display a strong spatial association with $\mathrm{D}_{2}$ structures including the Sladen fault, and the NW-SE deformation zones (Fig. 3; Sansfaçon, 1986; De Souza et al., 2016). At the district scale, this association is manifested by the consistent distribution of the gold showings (weakly mineralized) along strike with the $\mathrm{S}_{2}$ foliation (Fig. 2). Most of the lithogeochemical anomalies, notably those delineated by the pathfinder trace elements, reflect this structural control and form elongated haloes that extend parallel to the $S_{2}$ fabric (Fig. 12).

The geometry of the metasomatic envelopes may also be affected by the superposition of metamorphic and/or deformation events. At Canadian Malartic, gold mineralization is interpreted to have formed earlyto syn-peak metamorphism $\left(\mathrm{M}_{2}\right)$ (Gaillard et al., 2018). For this reason, it is possible that the alteration 
614 footprint associated with ore-forming processes was modified during metamorphism, which increased in

615 grade from upper greenschist facies adjacent to the deposit, to mid-amphibolite facies a few kilometers to

616 the south (Fig. 2). Most significantly, the transition from greenschist to amphibolite facies is generally

617 associated with a series of devolatilization reactions, which typically coincide with a release of sulfur

618 associated with the conversion of pyrite to pyrrhotite (Pitcairn et al., 2006; Phillips and Powell, 2010;

619 Gaillard et al., in review). The latter reaction may also play a critical role in the liberation of pyrite-hosted

620 trace metals (e.g., Au and related elements) to the metamorphic fluids (Pitcairn et al., 2010). In the Malartic

621 district, devolatilization associated with increasing metamorphic grade likely contributed to a southward

622 decrease in the concentrations of these elements in the background metasedimentary rocks (Fig. 12). Most

623 notably, loss on ignition (LOI), sulfur and carbon, as well as metals liberated during pyrite (e.g., Au, As,

$624 \mathrm{Te}, \mathrm{Bi})$ and $\mathrm{Fe}-\mathrm{Ti}$ oxide $($ e.g., W, Sb) breakdown represent variables that may have been mobilized along

625 the metamorphic gradient.

\subsection{Implications for mineral exploration}

The results of mass transfer calculations display a progressive increase in the concentrations of C-S- $\mathrm{K}_{2} \mathrm{O}$

and $\mathrm{LOI}$, as well as $\mathrm{Au}-\mathrm{Te}-\mathrm{W}-\mathrm{Ag} \pm(\mathrm{As}-\mathrm{Be}-\mathrm{Sb}-\mathrm{Bi}-\mathrm{Mo}-\mathrm{Pb})$ from background to distal and proximal alteration zones (Figs. 8-9). Enrichment patterns are shown to delineate broad metasomatic envelopes around the deposit, and were used to trace the location of hydrothermal fluid-rock interaction in the Malartic district

631 (Fig. 12). The statistical approach based on the comparison of the mass balance results with the background composition provides robust constraints on the magnitude and extent of the lithogeochemical haloes. Here, we use this information to identify the components that are most likely to provide exploration vectors towards gold mineralization.

The pathfinder elements define extensive alteration footprints around the Canadian Malartic deposit, in sharp contrast with the background metasedimentary rocks (Fig. 12A-G). The anomalies delineated by

$637 \mathrm{Au}, \mathrm{Te}, \mathrm{W}$ and $\mathrm{Ag}$ form the largest metasomatic haloes, reaching up to $10 \mathrm{~km}$ in length and $2 \mathrm{~km}$ in width 638 (Fig. 12A-D). Because they display a strong metasomatic signal and are only weakly affected by outliers, $639 \mathrm{~W}$, and to a lesser extent, Te and Ag, provide the best vectors towards gold mineralization. By contrast, 640 other pathfinder elements, including $\mathrm{As}, \mathrm{Be}$ and $\mathrm{Sb}$ form generally asymmetric haloes around the deposit, 641 and display several false positive anomalies, thereby hindering potential applications as ore-vectoring tools 642 (Fig. 12E-H). Carbon, S and LOI outline district-scale geochemical haloes enveloping gold mineralization; 
however, these variables are also affected by the presence of outliers that obscure gradients toward hydrothermal centers (Fig. 12I-J,L). Finally, the potassic halo defined by $\mathrm{K}_{2} \mathrm{O}$ enrichment provides a useful proxy for hydrothermal alteration, although it is mainly restricted to the immediate deposit area (Fig. 12K).

The mass transfer data for the Malartic district represent compositional vectors that can also be applied more widely for gold exploration in metamorphic terranes. In fact, the $\mathrm{Au}-\mathrm{Te}-\mathrm{W}-\mathrm{Ag} \pm(\mathrm{As}-\mathrm{Sb}-\mathrm{Bi}-\mathrm{Mo}-\mathrm{Pb})$ signature of the ore assemblage displays strong similarities with other intrusion-related and orogenic-type gold deposits (Robert and Poulsen, 1997; Brauhart et al., 2017). Notably, W, Te and Ag have also been shown to provide vectors toward gold mineralization in the Red Lake (Stock, 2012) and Norseman-Wiluna (Eilu and Groves, 2001; Prendergast, 2007) greenstone belts, and in the Lachlan fold belt (Bierlein et al., 2000). In these locations, pathfinder elements were used to detect the cryptic effects of alteration a few tens of meters, and more rarely up to several kilometers away from the fluid corridors.

The nature of hydrothermal alteration varies as a function of host-rock lithology (Bierlein et al., 2000). A companion study conducted by Perrouty et al. (2018) on mafic dykes is used to assess such lithological controls on alteration processes in the Malartic district. A comparison of the lithogeochemical anomalies in mafic dykes and metasedimentary rocks shows several differences in the magnitude and distribution of the metasomatic haloes. The results indicate that carbon and alkaline elements $(\mathrm{K}, \mathrm{Cs}, \mathrm{Rb})$ delineate larger anomalies in the mafic dykes, whereas pathfinder element (W, Te, Ag) anomalies generally extend farther in the metasedimentary rocks. These observations thus suggest a strong lithological control on the chemical reactivity and precipitation of ore-fluid components. This information may be used in mineral exploration to enhance the detection of cryptic alteration through the careful selection of the most reactive target media, and comparison of the results between different rock types.

\section{Conclusions}

This study demonstrates that whole-rock lithogeochemistry is a valuable tool for mapping the intensity and distribution of hydrothermal alteration in the Malartic district. Mass change results provide insights into metasomatic effects associated with ore-forming processes, and can be used to identify the components that are potentially most useful as vectors to gold mineralization. The signature of the mineralized system is characterized by strong enrichments compared to least altered equivalents in C-S- $\mathrm{K}_{2} \mathrm{O}-\mathrm{LOI}$, as well as $\mathrm{Au}-\mathrm{Te}-\mathrm{W}-\mathrm{Ag} \pm(\mathrm{As}-\mathrm{Be}-\mathrm{Sb}-\mathrm{Bi}-\mathrm{Mo}-\mathrm{Pb})$, with increasing intensities from background, to distal and proximal alteration zones. Molar element ratio analysis also provides a means with which to assess the mineralogical 
672

673

674

675

676

677

678

679

680

681

682

683

684

685

686

687

688

689

690

691

692

controls associated with alkali metasomatism ( $\mathrm{K}$ and $\mathrm{Na}$ ), and illustrates a progressive increase in the proportions of microcline and albite adjacent to fluid pathways (at the expense of biotite and white mica).

Enrichment patterns defined by pathfinder elements outline broad lithogeochemical anomalies around the deposit, and can be used to trace hydrothermal fluid-rock interaction in the district. The alteration haloes generally consist of elongate envelopes oriented parallel to the foliation $\left(\mathrm{S}_{2}\right)$, with a lateral extent reaching up to several kilometers away from the deposit. Notably, Au, W, Te and Ag delineate the largest anomalies, and define semi-continuous alteration footprints reaching approximately $10 \mathrm{~km}$ in length and $2 \mathrm{~km}$ in width. These results demonstrate that the lithogeochemical approach provides a valuable vectoring tool toward gold mineralization in metamorphic terranes, and can be used to recognize even cryptic alteration associated with ore-forming processes at the district-scale.

\section{Acknowledgements}

Funding for this study was provided by the Natural Sciences and Engineering Council (NSERC) and the Canada Mining Innovation Council through the collaborative research and development program (CRD). We are grateful to Canadian Malartic Corporation for logistical support and assistance during fieldwork. N. Piette-Lauzière, P. Lypaczewski, T. Raskevicius and C. L.-Bérubé participated in fieldwork and sample collection. We are grateful to E. Grunsky for insightful discussions on data analysis and statistical methods. We thank our fellow researchers of the NSERC-CMIC Footprints project for fruitful discussions and continuous support: S. Piercey, G. Olivo, R. Wares, M. Bardoux, G. Beaudoin, D. Béziat, C. Guilmette, H. Poulsen, K. Kyser, F. Robert, A. Galley and M. Lesher. We gratefully acknowledge the valuable assistance and feedback provided by the industry sponsors. NSERC-CMIC Mineral Exploration Footprints Project Contribution 193. 


\section{REFERENCES}

Aitchison, J., 1986, The Statistical Analysis of Compositional Data. Monographs on Statistics and Applied Probability. Chapman \& Hall, Ltd. London, UK, p. 416

Ayer, J., Amelin, Y., Corfu, F., Kamo, S., Ketchum, J., Kwok, K., and Trowell, N., 2002, Evolution of the southern Abitibi greenstone belt based on $\mathrm{U}-\mathrm{Pb}$ geochronology: autochthonous volcanic construction followed by plutonism, regional deformation and sedimentation: Precambrian Research, v. 115, p. 63-95.

Ayer, J. A., Thurston, P. C., Bateman, R., Dubé, B., Gibson, H. L., Hamilton, M. A., Hathway, B., Hocker, S. M., Houlé, M. G., Hudak, G., Ispolatov, V. O., Lafrance, B., Lesher, C. M., MacDonald, P. J., Péloquin, A. S., Piercey, S. J., Reed, L. E., and Thompson, P. H., 2005, Overview of results from the Greenstone Architecture Project: Discover Abitibi Initiative: Ontario Geological Survey, Open File Report 6154, p. 146

Bedeaux, P., Mathieu, L., Pilote, P., Rafini, S., and Daigneault, R., 2018, Origin of the Piché Structural Complex and implications for the early evolution of the Archean crustal-scale Cadillac-Larder Lake Fault Zone, Canada: Canadian Journal of Earth Sciences, p. 1-18.

Bedeaux, P., Pilote, P., Daigneault, R., and Rafini, S., 2017, Synthesis of the structural evolution and associated gold mineralization of the Cadillac Fault, Abitibi, Canada: Ore Geology Reviews, v.82, p. 49-69

Benn, K., Miles, W., Ghassemi, M. R., and Gillett, J., 1994, Crustal structure and kinematic framework of the northwestern Pontiac Subprovince, Quebec: an integrated structural and geophysical study: Canadian Journal of Earth Sciences, v. 31, p. 271-281.

Bierlein, F. P., Arne, D. C., McKnight, S., Lu, J., Reeves, S., Besanko, J., Marek, J., and Cooke, D., 2000, Wall-Rock Petrology and Geochemistry in Alteration Halos Associated with Mesothermal Gold Mineralization, Central Victoria, Australia: Economic Geology, v. 95, p. 283-311.

Bierlein, F. P., Fuller, T., Stüwe, K., Arne, D. C., and Keays, R. R., 1998, Wallrock alteration associated with turbidite-hosted gold deposits. Examples from the Palaeozoic Lachlan Fold Belt in central Victoria, Australia: Ore Geology Reviews, v. 13, p. 345-380.

Bleeker, W., 2015, Synorogenic gold mineralization in granite-greenstone terranes: the deep connection between extension, major faults, synorogenic clastic basins, magmatism, thrust inversion, and long-term preservation: Targeted Geoscience Initiative 4: Contributions to the Understanding of Precambrian Lode Gold Deposits and Implications for Exploration, v. B. Dubé and P. Mercier-Langevin; Geological Survey of Canada, Open File 7852, p. 27-47.

Brauhart, C. W., Grunsky, E. C., and Hagemann, S. G., 2017, Magmato-hydrothermal space: A new metric for geochemical characterisation of metallic ore deposits: Ore Geology Reviews, v. 86, p. 867-895.

Cai, G., Guo, F., Liu, X., Sui, S., Li, C., and Zhao, L., 2008, Geochemistry of Neogene sedimentary rocks from the Jiyang basin, North China Block: The roles of grain size and clay minerals: Geochemical Journal, v. 42 , p. $381-402$.

Camiré, G. E., and Burg, J. P., 1993, Late Archaean thrusting in the northwestern Pontiac Subprovince, Canadian Shield: Precambrian Research, v. 61, p. 51-66.

Camiré, G. E., Laflèche, M. R., and Ludden, J. N., 1993a, Archaean metasedimentary rocks from the northwestern Pontiac Subprovince of the Canadian shield: chemical characterization, weathering and modelling of the source areas: Precambrian Research, v. 62, p. 285-305.

Card, K. D., and Poulsen, K. H., 1998, Geology and mineral deposits of the Superior province of the Canadian Shield: Geology of Canada Series no. 7, v. in, Geology of the Precambrian Superior and Grenville provinces and Precambrian fossils in North America, p. 15-204. 
Chown, E. H., Harrap, R., and Moukhsil, A., 2002, The role of granitic intrusions in the evolution of the Abitibi belt, Canada: Precambrian Research, v. 115, p. 291-310.

Clark, M. E., Carmichael, D. M., Hodgson, C. J., and Fu, M., 1989, Wall-rock alteration, Victory Gold Mine, Kambalda, Western Australia: processes and P-T-X $(\mathrm{CO} 2)$ conditions of metasomatism Economic Geology Monograph 6, p. 445-459.

Daigneault, R., Mueller, W. U., and Chown, E. H., 2002, Oblique Archean subduction: accretion and exhumation of an oceanic arc during dextral transpression, Southern Volcanic Zone, Abitibi Subprovince Canada: Precambrian Research, v. 115, p. 261-290.

Davies, J. F., and Whitehead, R. E., 2006, Alkali-Alumina and MgO-Alumina Molar Ratios of Altered and Unaltered Rhyolites, p. 75-88

Davis, D. W., 2002, U-Pb geochronology of Archean metasedimentary rocks in the Pontiac and Abitibi subprovinces, Quebec, constraints on timing, provenance and regional tectonics: Precambrian Research, v. 115 , p. 97-117.

Davis, W. J., Lacroix, S., Gariépy, C., and Machado, N., 2000, Geochronology and radiogenic isotope geochemistry of plutonic rocks from the central Abitibi subprovince: significance to the internal subdivision and plutono-tectonic evolution of the Abitibi belt: Canadian Journal of Earth Sciences, v. 37, p. 117-133.

De Souza, S., Dubé, B., McNicoll, V. J., Dupuis, C., Mercier-Langevin, P., Creaser, R. A., and Kjarsgaard, I. M., 2015, Geology, hydrothermal alteration, and genesis of the world-class Canadian Malartic stockworkdisseminated Archean gold deposit, Abitibi, Quebec: Targeted Geoscience Initiative 4: Contributions to the Understanding of Precambrian Lode Gold Deposits and Implications for Exploration, B. Dubé and P. Mercier-Langevin; Geological Survey of Canada, Open File 7852, p. 113-126.

De Souza, S., Dubé, B., McNicoll, V. J., Dupuis, C., Mercier-Langevin, P., Creaser, R. A., and Kjarsgaard, I. M., 2016, Geology and hydrothermal alteration of the world-class Canadian Malartic gold deposit: genesis of an Archean stockwork-disseminated gold deposit in the Abitibi Greenstone Belt, Québec: Reviews in Economic Geology, v. 19, p. 29.

Derry, D. R., 1939, The geology of the Canadian Malartic gold mine, N. Quebec: Economic Geology, v. 34, p. 495-523.

Desrochers, J.-P., and Hubert, C., 1996, Structural evolution and early accretion of the Archean Malartic Composite Block, southern Abitibi greenstone belt, Quebec, Canada: Canadian Journal of Earth Sciences, v. 33, p. 1556-1569.

Dimroth, E., Imreh, L., Rocheleau, M., and Goulet, N., 1982, Evolution of the south-central part of the Archean Abitibi Belt, Quebec. Part I: Stratigraphy and paleogeographic model: Canadian Journal of Earth Sciences, v. 19, p. 1729-1758.

Eilu, P., and Groves, D. I., 2001, Primary alteration and geochemical dispersion haloes of Archaean orogenic gold deposits in the Yilgarn Craton: the pre-weathering scenario: Geochemistry: Exploration, Environment, Analysis, v. 1, p. 183-200.

Eilu, P., and Mikucki, E. J., 1998, Alteration and primary geochemical dispersion associated with the Bulletin lode-gold deposit, Wiluna, Western Australia: Journal of Geochemical Exploration, v. 63, p. 73103.

Eilu, P., Mikucki, J. E., and Dugdale, L. A., 2001, Alteration zoning and primary geochemical dispersion at the Bronzewing lode-gold deposit, Western Australia: Mineralium Deposita, v. 36, p. 13-31.

Eilu, P. K., 1999, Atlas of alteration assemblages, styles and zoning in orogenic lode-gold deposits in a variety of host rock and metamorphic settings 
Fallara, F., Simon-Ross, P., and Sansfaçon, R., 2000, Caractérisation géochimique, pétrographique et structurale : nouveau modèle métallogénique du camp minier de Malartic: Géologie Québec, MB 2000-15.

Finlow-Bates, T., and Stumpfl, E. F., 1981, The behaviour of so-called immobile elements in hydrothermally altered rocks associated with volcanogenic submarine-exhalative ore deposits: Mineralium Deposita, v. 16, p. 319-328.

Frieman, B. M., Kuiper, Y. D., Kelly, N. M., Monecke, T., and Kylander-Clark, A., 2017, Constraints on the geodynamic evolution of the southern Superior Province: U-Pb LA-ICP-MS analysis of detrital zircon in successor basins of the Archean Abitibi and Pontiac subprovinces of Ontario and Quebec, Canada: Precambrian Research, v. 292, p. 398-416.

Gaillard, N., E., W.-J. A., R., C. J., Salvi, S., Perrouty, S., and Linnen, R. L., Submitted, Reconstructing hydrothermal and metamorphic paths using textural, modal and mineral-chemical features of pyrite and pyrrhotite: Vectoring to gold mineralization in the Malartic district, Québec.

Gaillard, N., Williams-Jones, A. E., Clark, J. R., Lypaczewski, P., Salvi, S., Perrouty, S., Piette-Lauzière, N., Guilmette, C., and Linnen, R. L., 2018, Mica composition as a vector to gold mineralization: Deciphering hydrothermal and metamorphic effects in the Malartic district, Quebec: Ore Geology Reviews, v. 95, p. $789-820$.

Gaillard, N., Williams-Jones, A. E., Clark, J. R., Salvi, S., Béziat, D., Lypaczewski, P., Perrouty, S., and Linnen, R. L., 2015, Mineralogical and geochemical vectors to ore: the alteration halo of the Canadian Malartic gold deposit.: Proceedings of the 13th, Biennial SGA Meeting, Nancy, France. , v. 2, p. 461-464.

Gao, J.-F., Jackson, S. E., Dubé, B., Kontak, D. J., and De Souza, S., 2015, Genesis of the Canadian Malartic, Côté Gold, and Musselwhite gold deposits: insights from LA-ICP-MS element mapping of pyrite: Targeted Geoscience Initiative 4: Contributions to the Understanding of Precambrian Lode Gold Deposits and implications for exploration. B. Dubé and P. Mercier-Langevin; Geological Survey of Canada, Open File 7852, p. 157-175.

Ghassemi, M. R., 1996, Tectonic evolution of the Late Archean Pontiac Subprovince, Superior Province, Canada: Structural, metamorphic and geochronological studies: Ph.D. thesis, University of Ottawa.

Goldfarb, R. J., Baker, T., Dube, B., Groves, D. I., Hart, C. J. R., and Gosselin, P., 2005, Distribution, character, and genesis of gold deposits in metamorphic terranes: Economic Geology and the bulletin of the Society of Economic Geologists, 100th Anniversary Volume 1905-2005; In: Hedenquist, J.W.; Thompson, J.F.H.; Goldfarb, R.J.; and Richards, J.P. (eds.), p. 407-450.

Goulet, N., 1978, Stratigraphy and structural relationships across the Cadillac-Larder lake fault, RouynBeauchastel area, Quebec: Ministère des Ressources Naturelles du Quebec, DP-602, p. 141.

Grant, J. A., 1986, The isocon diagram; a simple solution to Gresens' equation for metasomatic alteration: Economic Geology, v. 81, p. 1976-1982.

Gresens, R. L., 1967, Composition-volume relationships of metasomatism: Chemical Geology, v. 2, p.4765.

Gunning, H. C., and Ambrose, J. W., 1943, Région de Malartic, Québec: Commission géologique du Canada, Mémoire 222, p. 162 (12 feuilles).

Halley, S., Dilles, J. H., and Tosdal, R. M., 2015, Footprints: hydrothermal alteration and geochemical dispersion around porphyry copper deposits: SEG newsletter, v. 100.

Helsel, D. R., 2005, Non-detects and data analysis: Statistics for censored environmental data, John Wiley \& Sons. 
Helsel, D. R., and Gilliom, R. J., 1986, Estimation of distributional parameters for censored trace level water quality data: 1. Estimation techniques: Water Resources Research, v. 22, p. 147-155.

Helt, K. M., Williams-Jones, A. E., Clark, J. R., Wing, B. A., and Wares, R. P., 2014, Constraints on the Genesis of the Archean Oxidized, Intrusion-Related Canadian Malartic Gold Deposit, Quebec, Canada: Economic Geology, v. 109, p. 713-735.

Hron, K., Templ, M., and Filzmoser, P., 2010, Imputation of missing values for compositional data using classical and robust methods: Computational Statistics \& Data Analysis, v. 54, p. 3095-3107.

Hubert, C., Trudel, P., and Gélinas, L., 1984, Archean wrench fault tectonics and structural evolution of the Blake River Group, Abitibi Belt, Quebec: Canadian Journal of Earth Sciences, v. 21, p. 1024-1032.

Huston, C., and Juarez-Colunga, 2009, Guidelines for computing summary statistics for data-sets containing non-detects.

Imreh, L., 1984, Sillon de la Motte-Vassan et son avant-pays méridional; synthese volcanologique, lithostratigraphique et gitologique. : Ministère des Ressources Naturelles, The La Motte-Vassan Structure and its southern foreland; volcanologic, lithostratigraphic and economic synthesis., p. 72.

Knight, J. T., Ridley, J. R., and Groves, D. I., 2000, The Archean Amphibolite Facies Coolgardie Goldfield, Yilgarn Craton, Western Australia: Nature, Controls, and Gold Field-Scale Patterns of Hydrothermal WallRock Alteration: Economic Geology, v. 95, p. 49-84.

Korzhinskii, D. S., 1968, The theory of metasomatic zoning: Mineralium Deposita, v. 3, p. 222-231.

Libbey, R. B., and Williams-Jones, A. E., 2016, Lithogeochemical approaches in geothermal system characterization: An application to the Reykjanes geothermal field, Iceland: Geothermics, v. 64, p. 61-80.

Limpert, E., Stahel, W. A., and Abbt, M., 2001, Log-normal Distributions across the Sciences: Keys and CluesOn the charms of statistics, and how mechanical models resembling gambling machines offer a link to a handy way to characterize log-normal distributions, which can provide deeper insight into variability and probability—normal or log-normal: That is the question: BioScience, v. 51, p. 341-352.

Lypaczewski, P., Rivard, B., Gaillard, N., Perrouty, S., Piette-Lauzière, N., Bérubé, C. L., and Linnen, R. L., Submitted, Using hyperspectral imaging as a vector towards mineralization at the Canadian Malartic gold deposit, Quebec, Canada.

MacLean, W. H., 1990, Mass change calculations in altered rock series: Mineralium Deposita, v. 25, p. 44-49.

MacLean, W. H., and Barrett, T. J., 1993, Lithogeochemical techniques using immobile elements: Journal of Geochemical Exploration, v. 48, p. 109-133.

MacLean, W. H., and Kranidiotis, P., 1987, Immobile elements as monitors of mass transfer in hydrothermal alteration; Phelps Dodge massive sulfide deposit, Matagami, Quebec: Economic Geology, v. 82, p. 951-962.

Madeisky, H. E., and Stanley, C. R., 1993, Lithogeochemical Exploration of Metasomatic Zones Associated with Volcanic-Hosted Massive Sulfide Deposits Using Pearce Element Ratio Analysis: International Geology Review, v. 35, p. 1121-1148.

Makvandi, S., Ghasemzadeh-Barvarz, M., Beaudoin, G., Grunsky, E. C., McClenaghan, M. B., Duchesne, C., and Boutroy, E., 2016, Partial least squares-discriminant analysis of trace element compositions of magnetite from various VMS deposit subtypes: Application to mineral exploration: Ore Geology Reviews, v. 78, p. 388-408. 
Mathieu, L., 2018, Quantifying hydrothermal alteration: A review of methods: Geosciences (Switzerland), v. 8 .

McCuaig, T. C., Kerrich, R., Groves, D. I., and Archer, N., 1993, The nature and dimensions of regional and local gold-related hydrothermal alteration in tholeiitic metabasalts in the Norseman goldfields: the missing link in a crustal continuum of gold deposits?: Mineralium Deposita, v. 28, p. 420-435.

McDonough, W., and Sun, S. S., 1995, The composition of the Earth, 1050-1056 p.

Mishra, M., and Sen, S., 2011, Geochemical signatures for the grain size variation in the siliciclastics of Kaimur Group, Vindhyan Supergroup from Markundi ghat, Sonbhadra district, (U.P.), India: Geochemistry International, v. 49, p. 274-290.

Mortensen, J. K., and Card, K. D., 1993, U-Pb age constraints for the magmatic and tectonic evolution of the Pontiac Subprovince, Quebec: Canadian Journal of Earth Sciences, v. 30, p. 1970-1980.

Nesbitt, B. E., 1986a, Oxide-sulfide-silicate equilibria associated with metamorphosed ore deposits; Part I, Theoretical considerations: Economic Geology, v. 81, p. 831-840.

Nesbitt, B. E., 1986b, Oxide-sulfide-silicate equilibria associated with metamorphosed ore deposits; Part II, Pelitic and felsic volcanic terrains: Economic Geology, v. 81, p. 841-856.

Palarea-Albaladejo, J., and Martín-Fernández, J. A., 2013, Values below detection limit in compositional chemical data: Analytica Chimica Acta, v. 764, p. 32-43.

Palarea-Albaladejo, J., and Martín-Fernández, J. A., 2015, zCompositions - R package for multivariate imputation of left-censored data under a compositional approach: Chemometrics and Intelligent Laboratory Systems, v. 143, p. 85-96.

Palarea-Albaladejo, J., Martín-Fernández, J. A., and Buccianti, A., 2014, Compositional methods for estimating elemental concentrations below the limit of detection in practice using R: Journal of Geochemical Exploration, v. 141, p. 71-77.

Pearce, T. H., 1968, A contribution to the theory of variation diagrams: Contributions to Mineralogy and Petrology, v. 19, p. 142-157.

Perrouty, S., Gaillard, N., Piette-Lauzière, N., Mir, R., Bardoux, M., Olivo, G. R., Linnen, R. L., Bérubé, C. L., Lypaczewski, P., Guilmette, C., Feltrin, L., and Morris, W. A., 2017, Structural setting for Canadian Malartic style of gold mineralization in the Pontiac Subprovince, south of the Cadillac Larder Lake Deformation Zone, Québec, Canada: Ore Geology Reviews, v. 84, p. 185-201.

Perrouty, S., Linnen, R. L., Lesher, M. C., Olivo, G. R., Piercey, S. J., Gaillard, N., Clark, J. R., and Enkin, R. J., In press, Expanding the size of multi-parameter metasomatic footprints in gold exploration: utilization of mafic dykes in the Canadian Malartic district, Québec, Canada: Mineralium Deposita.

Phillips, G. N., and Powell, R., 2010, Formation of gold deposits: a metamorphic devolatilization model: Journal of Metamorphic Geology, v. 28, p. 689-718.

Piercey, S. J., Ansdell, K., Beaudoin, G., Chouteau, M., Enkin, R. J., Gleeson, S., Hollings, P., LaytonMatthews, D., Lesher, C.M., Morris, B., Samson, I.M., et al., 2014, Sampling, Sample Processing, and Analytical Protocols, White Paper \#3, v2014.07.11

Piette-Lauzière, N., 2017, Métamorphisme régional du nord-est de la Sous-province de Pontiac, Abitibi, Québec Mémoire de Maîtrise en Sciences de la Terre, Université Laval.

Piette-Lauzière, N., Guilmette, C., Bouvier, A., Perrouty, S., Pilote, P., Gaillard, N., Lypaczewski, P., Linnen, R. L., and Olivo, G. R., Submitted, The Timing and Extent of Prograde Metamorphism in the 
Pontiac Subprovince, Superior Craton; Implications for Archean Geodynamics and Gold Mineralization: Precambrian Research.

Pilote, P., Daigneault, R., David, J., and McNicoll, V., 2015, Architecture of the Malartic, Piché and Cadillac groups and the Cadillac Fault: Geological revisions, new dates and interpretations., Ministère de l'Énergie et des Ressources Naturelles, p. 37.

Pitcairn, I. K., Olivo, G. R., Teagle, D. A. H., and Craw, D., 2010, Sulfide evolution during prograde metamorphism of the Otago and Alpine schists, New Zealand: The Canadian Mineralogist, v. 48, p. 12671295.

Pitcairn, I. K., Teagle, D. A. H., Craw, D., Olivo, G. R., Kerrich, R., and Brewer, T. S., 2006, Sources of Metals and Fluids in Orogenic Gold Deposits: Insights from the Otago and Alpine Schists, New Zealand: Economic Geology, v. 101, p. 1525-1546.

Powell, W. G., Hodgson, C. J., Hanes, J. A., Carmichael, D. M., Mcbride, S., and Farrar, E., 1995, 40Ar/39Ar geochronological evidence for multiple postmetamorphic hydrothermal events focused along faults in the southern Abitibi greenstone belt: Canadian Journal of Earth Sciences, v. 32, p. 768-786.

Prendergast, K., 2007, Application of lithogeochemistry to gold exploration in the St Ives goldfield, Western Australia: Geochemistry: Exploration, Environment, Analysis, v. 7, p. 99.

Rafini, S., 2014, Fiches descriptives de gites - Faille de Cadillac: Projet Consorem 2011-01 et 2012-01, p. 187.

Ricci-Lucchi, F., and Amorosi, A., 1978, Bedding and internal structures, Sedimentology: Berlin, Heidelberg, Springer Berlin Heidelberg, p. 85-98.

Ridley, J., Mikucki, E. J., and Groves, D. I., 1996, Archean lode-gold deposits: fluid flow and chemical evolution in vertically extensive hydrothermal systems: Ore Geology Reviews, v. 10, p. 279-293.

Robert, F., 2001, Syenite-associated disseminated gold deposits in the Abitibi greenstone belt, Canada: Mineralium Deposita, v. 36, p. 503-516.

Robert, F., and Poulsen, K. H., 1997, World-class Archaean gold deposits in Canada: An overview: Australian Journal of Earth Sciences, v. 44, p. 329-351.

Robert, F., Poulsen, K. H., Cassidy, K. F., and Hodgson, C. J., 2005, Gold Metallogeny of the Superior and Yilgarn Cratons: Economic Geology and the bulletin of the Society of Economic Geologists, 100th Anniversary Volume 1905-2005; In: Hedenquist, J.W.; Thompson, J.F.H.; Goldfarb, R.J.; and Richards, J.P. (eds.), p. 1001-1033.

Sansfaçon, R., 1986, The Malartic district: in Hubert, C., and Robert, F., eds., Structure and gold, Rouyn to Val d'Or, Québec: Geological Association of Canada-Mineralogical Association of Canada-Canadian Geophysical Union Joint Annual Meeting, Field Trip 14 Guidebook, Structure and gold, Rouyn to Val d'Or, Québec, p. 27-41.

Sansfaçon, R., Grant, M., and Trudel, P., 1987, Géologie de la mine Barnat - Sladen Malartic - District de Val d'Or -: Série des manuscripts bruts - Direction Générale de l'Exploration Géologique et Minérale, MB $87-41$.

Sansfaçon, R., Grant, M., and Trudel, P., 1987, Géologie de la mine Canadian Malartic - District de Val d'Or: Série des manuscripts bruts - Direction Générale de l'Exploration Géologique et Minérale, MB87-26

Sansfaçon, R., and Hubert, C., 1990, The Malartic Gold District, Abitibi greenstone belt, Québec: Geological setting, structure and timing of gold emplacement Barnat, East- Malartic, Canadian Malartic and Sladen Mines.: In: Rive, M., Verpealst, P., Gagnon, Y., Lulin, J.M., Riverin, G., Simard, A. (Eds.), The 
northwestern Quebec polymetallic belt: a summary of 60 years of mining exploration, Special Vol. 43., Canadian Institute of Mining and Metallurgy, p. 221-235.

Simard, M., Gaboury, D., Daigneault, R., and Mercier-Langevin, P., 2013, Multistage gold mineralization at the Lapa mine, Abitibi Subprovince: insights into auriferous hydrothermal and metasomatic processes in the Cadillac-Larder Lake Fault Zone: Mineralium Deposita, v. 48, p. 883-905.

Stanley, C. R., 2017, Molar Element Ratio Analysis of Lithogeochemical Data: A Toolbox for Use in Mineral Exploration and Mining: Proceedings of Exploration 17: Sixth Decennial International Conference on Mineral Exploration, edited by V. Tschirhart and M.D. Thomas, p. 471-494.

Stock, E. D., 2012, The mineralogical, geochemical and isotope characteristics of alteration, mineralization and metamorphism of the Red Lake Gold Mines, Ontario: Unpub. Text thesis.

Sutcliffe, R. H., Barrie, C. T., Burrows, D. R., and Beakhouse, G. P., 1993, Plutonism in the southern Abitibi Subprovince; a tectonic and petrogenetic framework: Economic Geology, v. 88, p. 1359-1375.

Thurston, P. C., Ayer, J. A., Goutier, J., and Hamilton, M. A., 2008, Depositional Gaps in Abitibi Greenstone Belt Stratigraphy: A Key to Exploration for Syngenetic Mineralization: Economic Geology, v. 103, p. 1097-1134.

Trudel, P., and Sauvé, P., 1992, Synthèse des caractéristiques géologiques des gisements d'or du district de Malartic: Direction Générale de l'Exploration Géologique et Minérale, MM 89-04.

Warren, I., Simmons, S. F., and Mauk, J. L., 2007, Whole-Rock Geochemical Techniques for Evaluating Hydrothermal Alteration, Mass Changes, and Compositional Gradients Associated with Epithermal Au-Ag Mineralization: Economic Geology, v. 102, p. 923-948.

Whitbread, M. A., and Moore, C. L., 2004, Two lithogeochemical approaches to the identification of alteration patterns at the Elura $\mathrm{Zn}-\mathrm{Pb}-\mathrm{Ag}$ deposit, Cobar, New South Wales, Australia: use of Pearce Element Ratio analysis and Isocon analysis: Geochemistry: Exploration, Environment, Analysis, v. 4, p. 129-141.

Wilkinson, L., Cruden, A. R., and Krogh, T. E., 1999, Timing and kinematics of post-Timiskaming deformation within the Larder Lake - Cadillac deformation zone, southwest Abitibi greenstone belt, Ontario, Canada: Canadian Journal of Earth Sciences, v. 36, p. 627-647. 


\section{FIGURES}



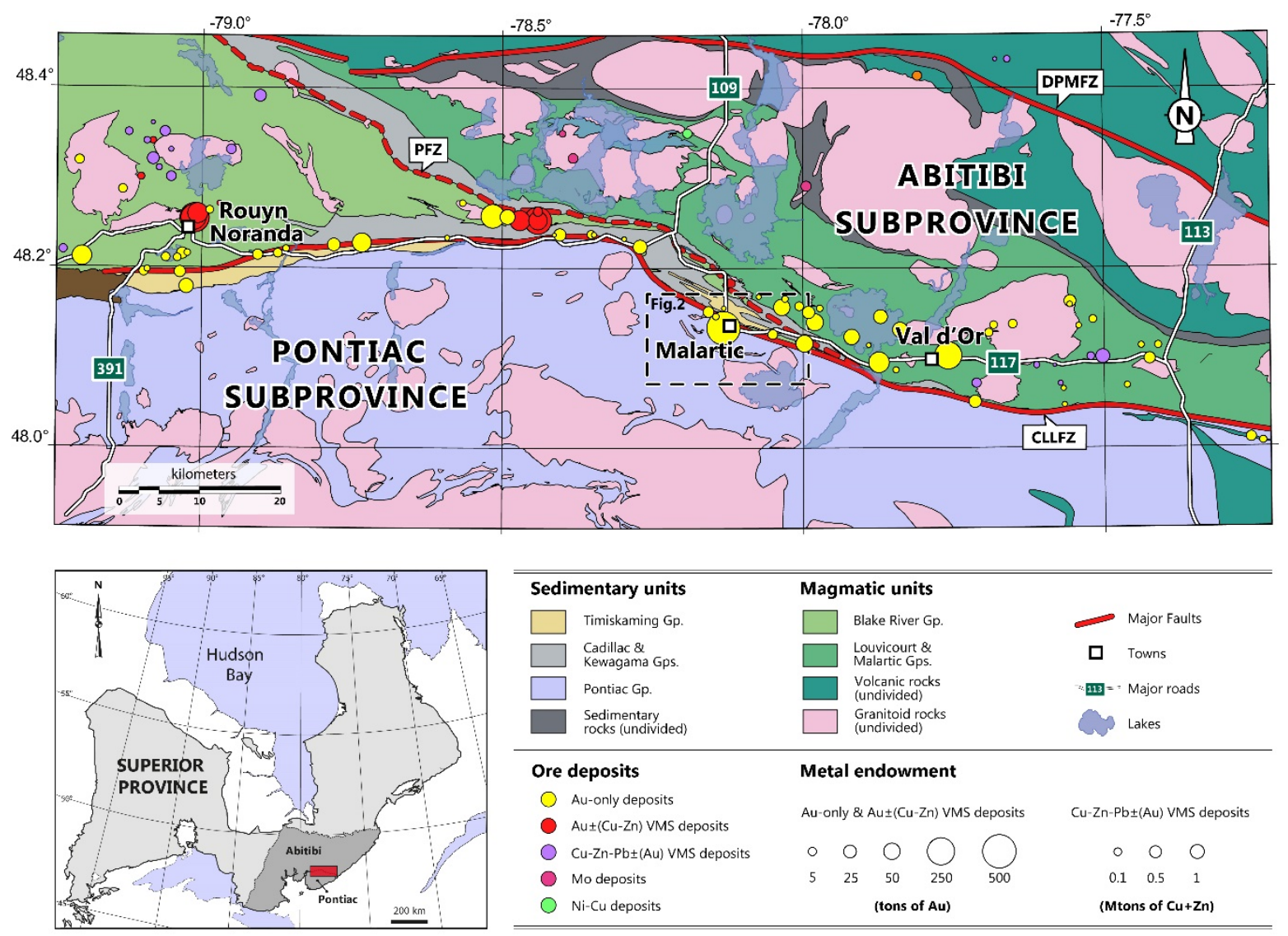

\begin{tabular}{|c|c|c|c|c|c|c|}
\hline \multicolumn{2}{|c|}{ Sedimentary units } & \multicolumn{5}{|c|}{ Magmatic units } \\
\hline & Timiskaming Gp. & & Blake River Gp. & \multicolumn{3}{|c|}{$\Longrightarrow$ Major Faults } \\
\hline & $\begin{array}{l}\text { Cadillac \& } \\
\text { Kewagama Gps. }\end{array}$ & & $\begin{array}{l}\text { Louvicourt \& } \\
\text { Malartic Gps. }\end{array}$ & $\square$ & \multicolumn{2}{|c|}{ Towns } \\
\hline & Pontiac Gp. & & $\begin{array}{l}\text { Volcanic rocks } \\
\text { (undivided) }\end{array}$ & $413=$ & \multicolumn{2}{|c|}{ Major roads } \\
\hline & $\begin{array}{l}\text { Sedimentary } \\
\text { rocks (undivided) }\end{array}$ & & $\begin{array}{l}\text { Granitoid rocks } \\
\text { (undivided) }\end{array}$ & & \multicolumn{2}{|l|}{ Lakes } \\
\hline \multicolumn{2}{|c|}{ Ore deposits } & \multicolumn{5}{|c|}{ Metal endowment } \\
\hline 0 & Au-only deposits & \multirow{2}{*}{\multicolumn{2}{|c|}{ Au-only \& Au士(Cu-Zn) VMS deposits }} & \multirow{2}{*}{\multicolumn{3}{|c|}{$\mathrm{Cu}-\mathrm{Zn}-\mathrm{Pb} \pm(\mathrm{Au})$ VMS deposits }} \\
\hline 0 & Aut(Cu-Zn) VMS deposits & & & & & \\
\hline 0 & $\mathrm{Cu}-\mathrm{Zn}-\mathrm{Pb} \pm(\mathrm{Au})$ VMS deposits & $\circ$ & 00 & & 0 & 0 \\
\hline 0 & Mo deposits & 5 & $25 \quad 50 \quad 250$ & & $1 \quad 0.5$ & 1 \\
\hline 0 & $\mathrm{Ni}-\mathrm{Cu}$ deposits & \multicolumn{2}{|r|}{ (tons of $\mathrm{Au}$ ) } & \multicolumn{3}{|c|}{ (Mtons of $\mathrm{Cu}+\mathrm{Zn}$ ) } \\
\hline
\end{tabular}

Figure 1: A regional lithostratigraphic map of the Abitibi and Pontiac subprovinces showing the locations of the main ore deposits along the Rouyn-Val d'Or segment (modified from Bedeaux et al., 2017; compiled from Hubert et al., 1984; Imreh, 1984; Desrochers and Hubert, 1996). Individual deposits are represented by colored circles that are scaled according to metal endowment, as calculated from past production and current reserve estimates (compiled from Rafini (2014), and references therein). Abbreviations: CLLFZ: Cadillac-Larder Lake Fault Zone; DPMFZ: Destor-Porcupine-Manneville Fault Zone; PFZ: Parfouru Fault Zone. 


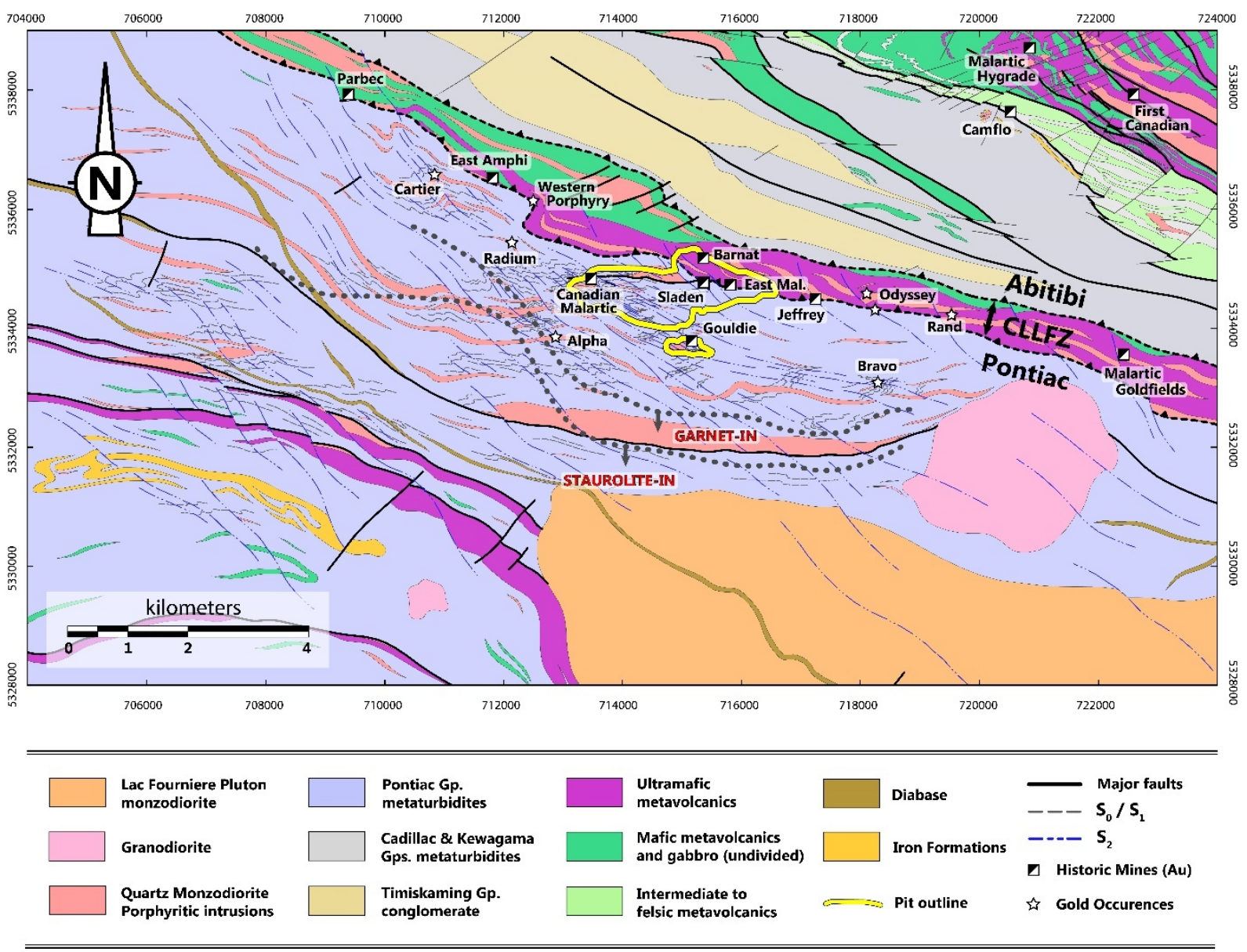

Figure 2: A lithostratigraphic map of the Malartic district showing the main structural, metamorphic and lithological features of the study area (modified from Perrouty et al., 2017; compiled from Derry, 1939; Gunning and Ambrose, 1943; Minerais Lac Limited maps; Sansfaçon et al., 1987a,b; Fallara et al., 2000; SIGEOM database, 2016; and references therein). The Canadian Malartic open-pit mine is delineated by a yellow outline. The map also displays the locations of the past-producing mines and gold occurrences. UTM Coordinate system NAD83-17N. Abbreviation: CLLFZ: Cadillac-Larder Lake Fault Zone. 


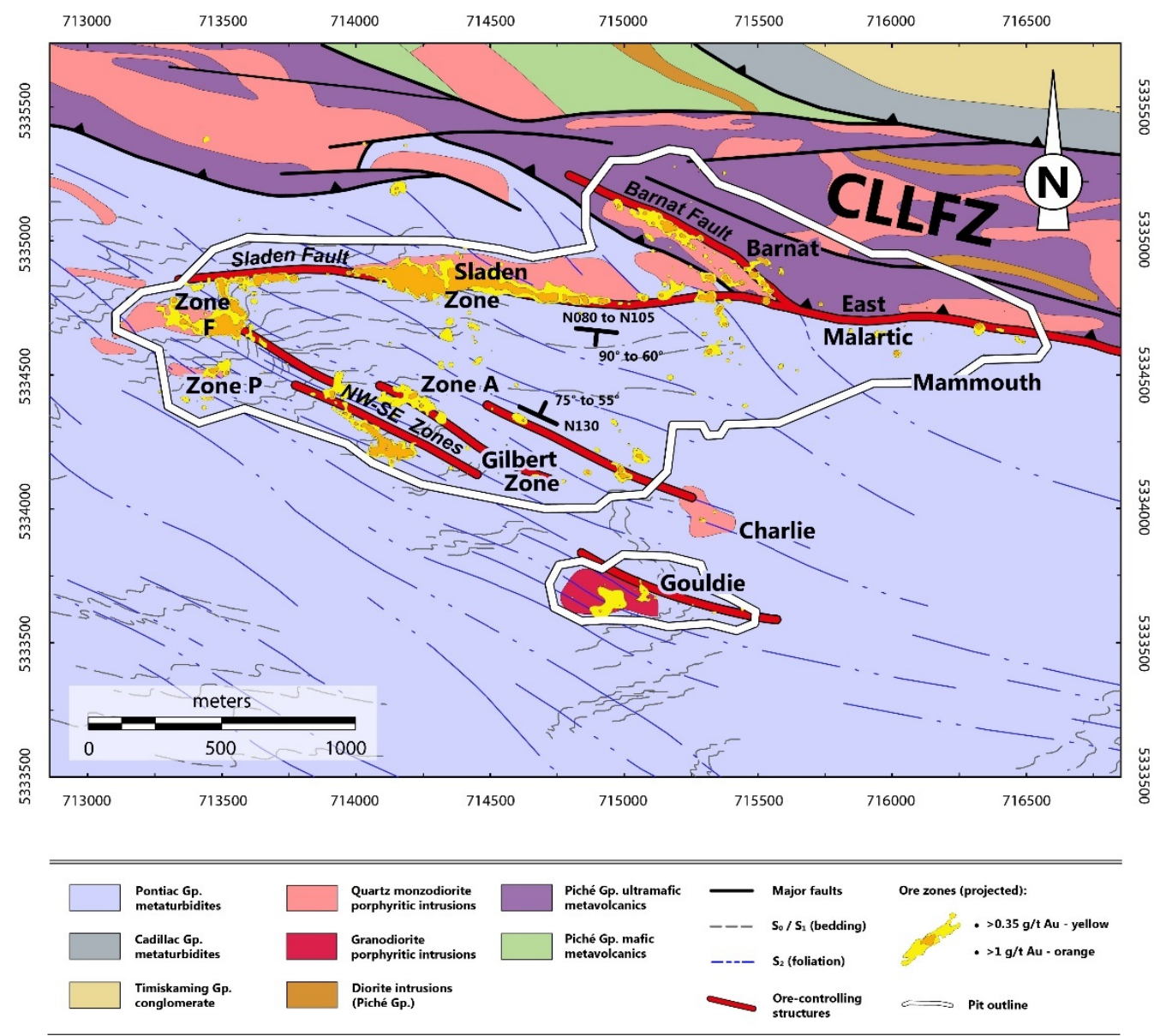

Figure 3: A geological map of the Canadian Malartic gold deposit (modified from Gaillard et al., 2018; compiled from MERN geological map CG-32D01D, Pilote, 2014; Perrouty et al., 2017; Canadian Malartic Corporation reports; and this study). Gold mineralized zones are projected from elevation $z=300 \pm 10 \mathrm{~m}$. Ore distribution is controlled predominantly by three structures, namely the Sladen and Barnat faults, and the NW-SE deformation zones. Abbreviation: CLLFZ: Cadillac-Larder Lake Fault Zone. 

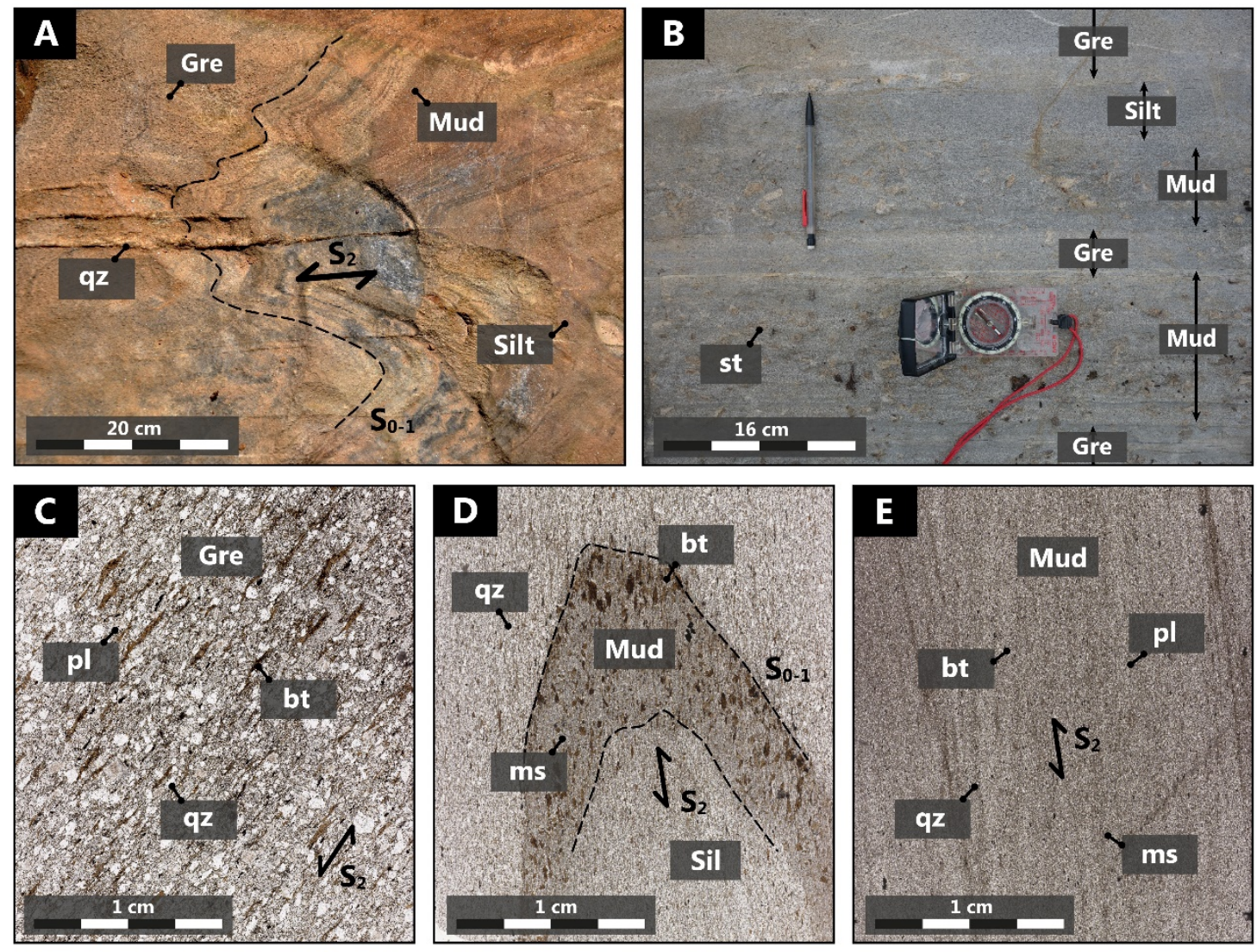

Figure 4: Representative characteristics of the host Pontiac Group metasedimentary rocks. A: A flyschoid sequence composed of mudstone to greywacke interstratified beds. The rocks were affected by $F_{2}$ folding and display a strong pervasive axial-planar foliation $\left(S_{2}\right)$. B: Local effects of the primary compositional variations on the mineralogy of the metamorphic assemblage in a planar-stratified turbiditic sequence. The staurolite porphyroblasts are restricted to the fine-grained pelitic beds (mudstone). C: A thin section image showing the textural characteristics of greywacke. The clastic particles of quartz and plagioclase reach up to $1 \mathrm{~mm}$ in diameter. $\boldsymbol{D}$ : A thin section image of a micro-folded $\left(F_{2}\right)$ sedimentary contact $\left(S_{0-1}\right)$. White mica is developed preferentially in the finer-grained, more aluminous mudstone. $\boldsymbol{E}$ : A thin section image showing the textural characteristics of mudstone. Detrital quartz and plagioclase grains are typically $<50 \mu m$ across. Abbreviations: bt: biotite; Gre: greywacke; ms: muscovite; Mud: mudstone; pl: plagioclase; qz: quartz; silt: Siltstone; st: staurolite. 

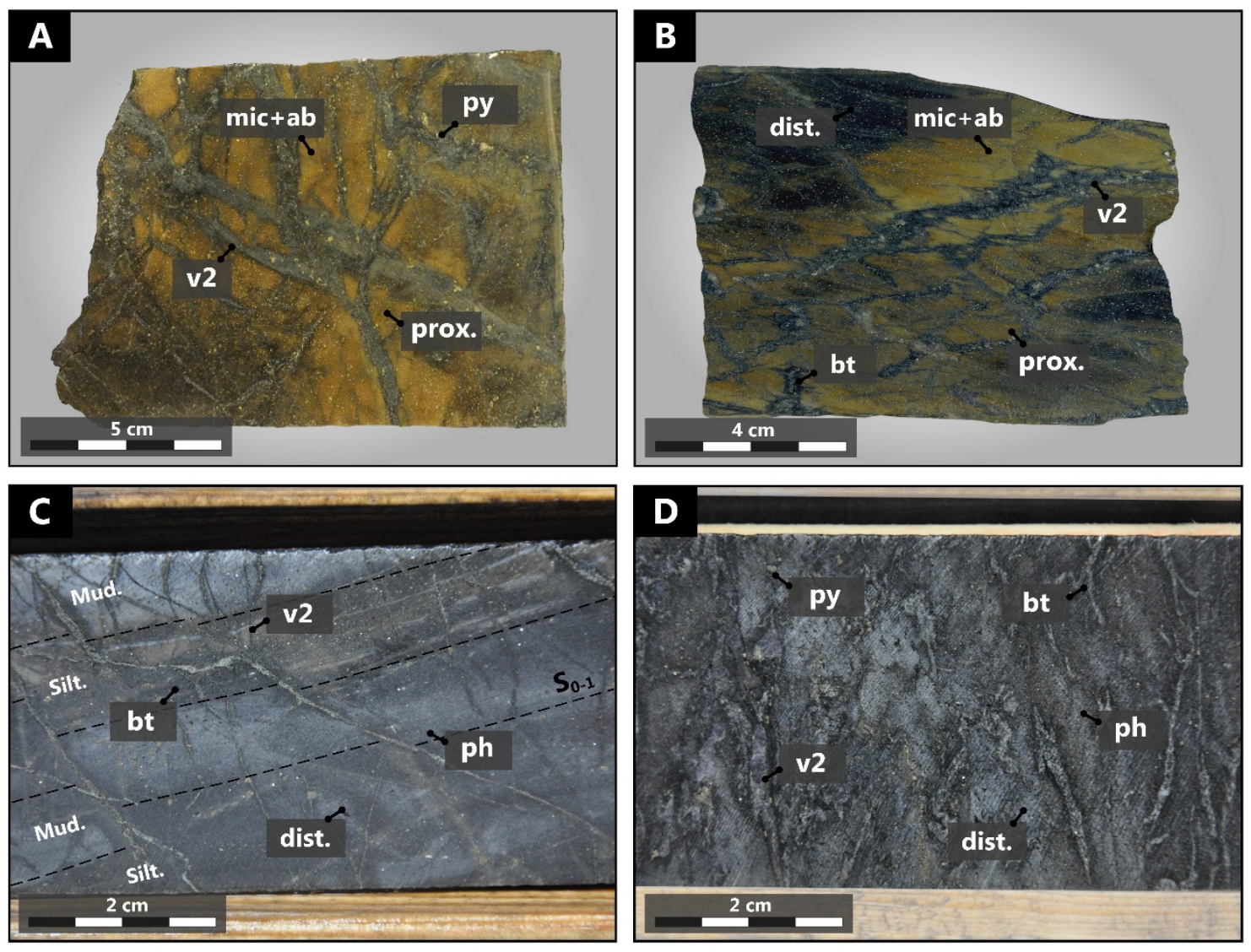

Figure 5: Representative characteristics of proximal and distal hydrothermal alteration assemblages in the metasedimentary rocks of the Canadian Malartic deposit. A-B: Proximal alteration is characterized by a beige/brown microcline \pm albite-quartz replacement-type assemblage, with subordinate phlogopite, carbonate (calcite $\pm F e$-dolomite), pyrite and rutile. This facies typically occurs in the form of a pervasive alteration envelope around ore-stage (v2) veinlets. C-D: Distal alteration consists of a blue/grey assemblage dominated by biotite, microcline \pm albite, phengite, quartz, calcite, pyrite and rutile. The mineralogy of the distal alteration is controlled in part by variations in protolith grain size; phengite alteration is generally best-developed in fine-grained mudstone layers. Abbreviations: ab: albite; bt: biotite; mic: microcline; ph: phengite; py: pyrite; qz: quartz. 

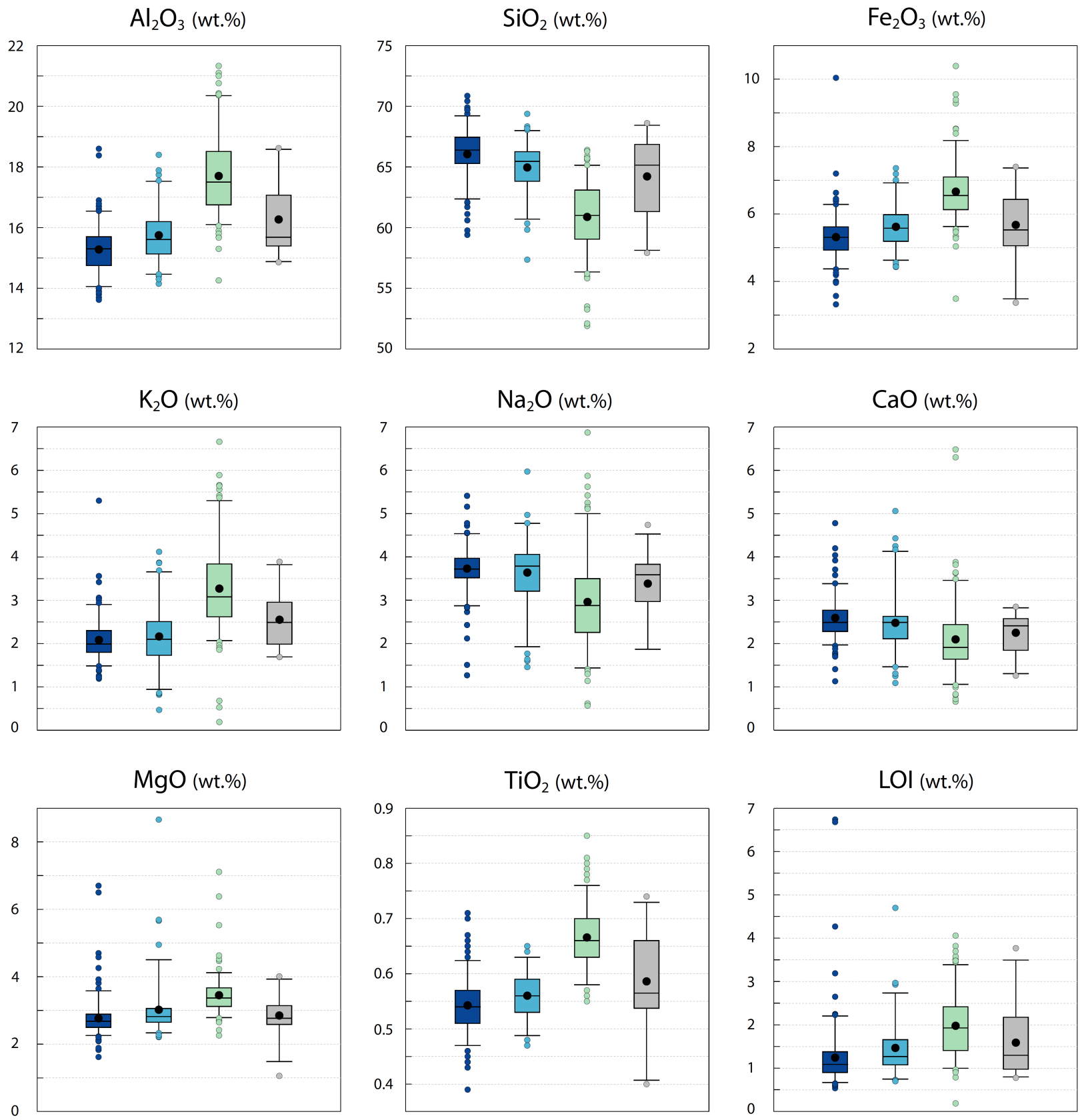

$$
\begin{gathered}
\text { Metasedimentary rock sub-lithologies: } \\
\begin{array}{cc}
\text { Greywacke } & \bigcirc \text { Mudstone } \\
\text { Siltstone } & \bigcirc
\end{array} \text { Low-LREE }
\end{gathered}
$$

Figure 6: A compilation of box and whisker plots showing primary whole-rock lithogeochemical variations (for major elements) among the main grain size fractions of the Pontiac Group metasedimentary rocks (background population; $n=443$ ). The samples were separated into four sub-lithologies, namely greywacke (dark blue; $n=171$ ), siltstone (medium blue; $n=87$ ), mudstone (green; $n=159)$ and low $\sum R E E$ (grey; $n=26$ ) rocks. The sediment compositions display generally clear and systematic variations with decreasing grain size. 

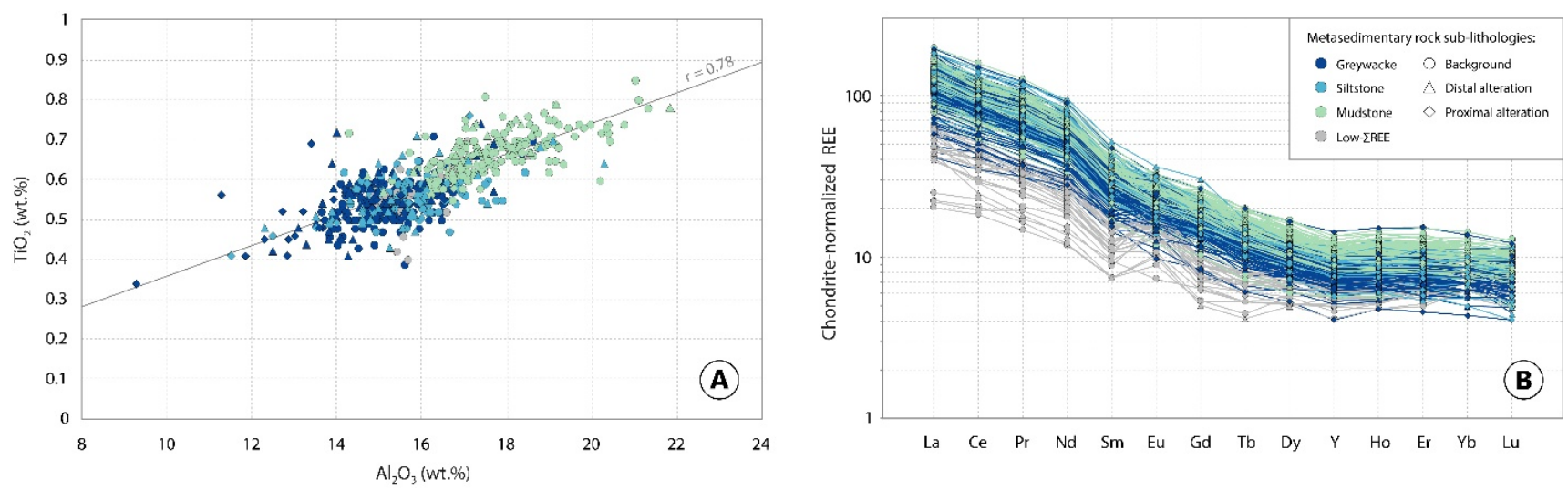

Figure 7: A: A positive correlation ( $r=0.78$ ) between $\mathrm{Al}_{2} \mathrm{O}_{3}$ and $\mathrm{TiO}_{2}$ bulk-rock concentrations (in wt.\%) suggests a strong cogenetic relationship for the Pontiac Group metasedimentary rock samples ( $n=596)$. The linear trend between $\mathrm{Al}_{2} \mathrm{O}_{3}$ and $\mathrm{TiO}_{2}$ concentrations further indicates that these elements remained immobile during alteration B: Chondrite-normalized REE patterns (Sun and McDonough, 1995) for the Pontiac Group greywacke $(n=247)$, siltstone $(n=134)$ and mudstone $(n=188)$ fractions are nearly identical and differ only in the absolute distribution of the REE. A separate group is defined by low $\sum R E E$ concentrations $(n=27)$ and a distinct chondrite-normalized REE profile. 

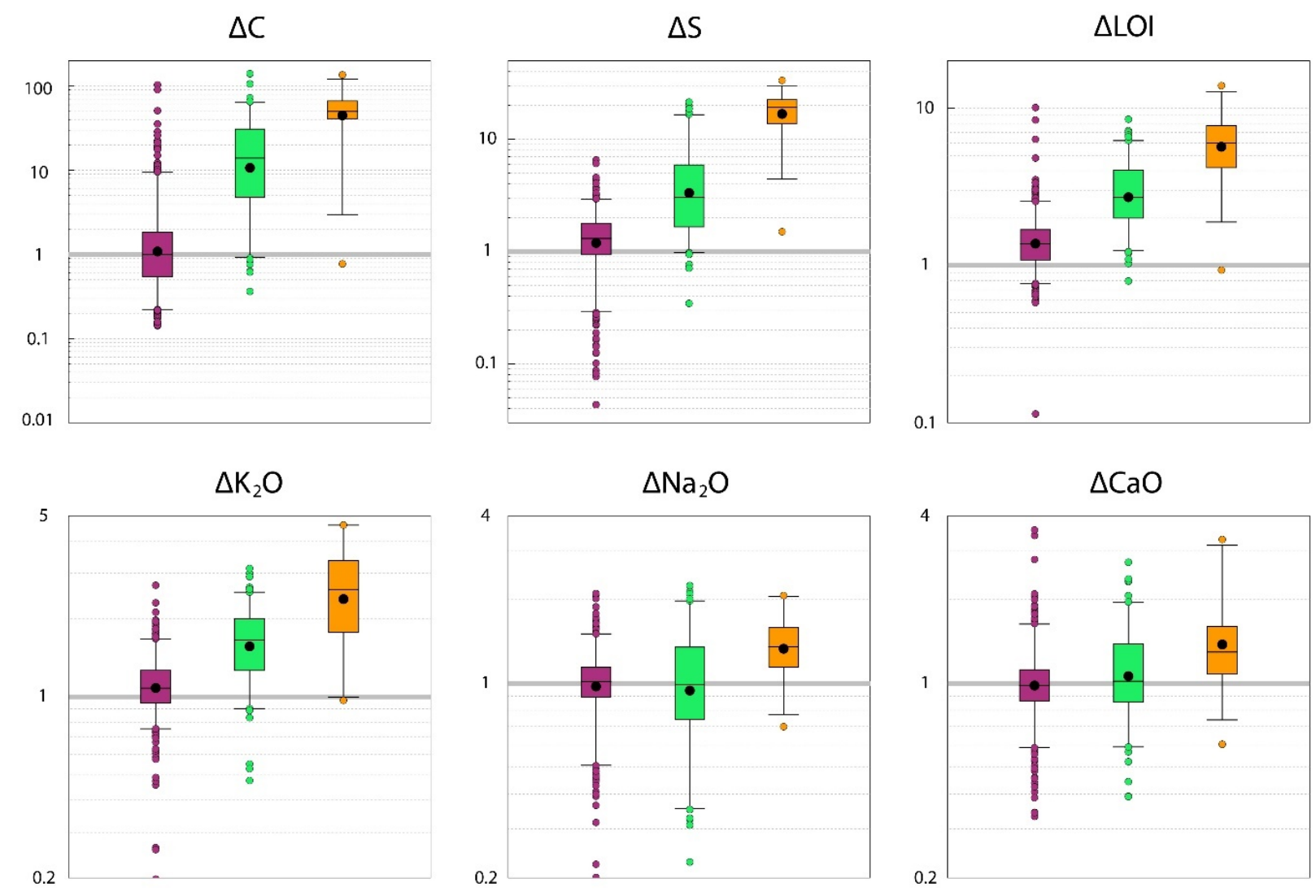

$$
\begin{aligned}
& \text { Proximal potassic alteration } \\
& \text { Distal potassic-sericitic alteration } \\
& \text { Background metasedimentary rocks }
\end{aligned}
$$

Figure 8: A compilation of box and whisker diagrams illustrating mass changes produced by hydrothermal alteration for select major elements in the metasedimentary rocks of the Malartic district. The samples were divided into three categories according to alteration characteristics, from background (in purple), to distal (in green) and proximal (in orange) alteration zones. 
$\triangle \mathrm{Au}$

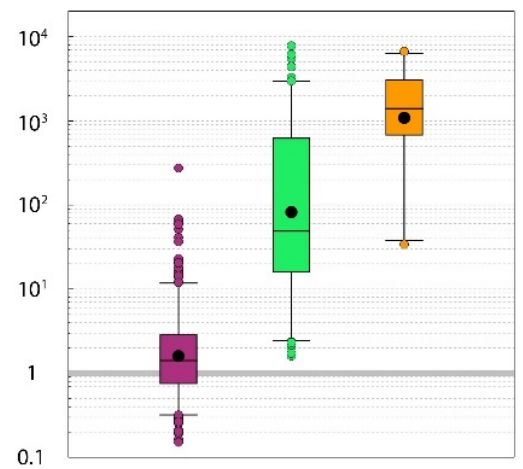

$\Delta \mathrm{Ag}$

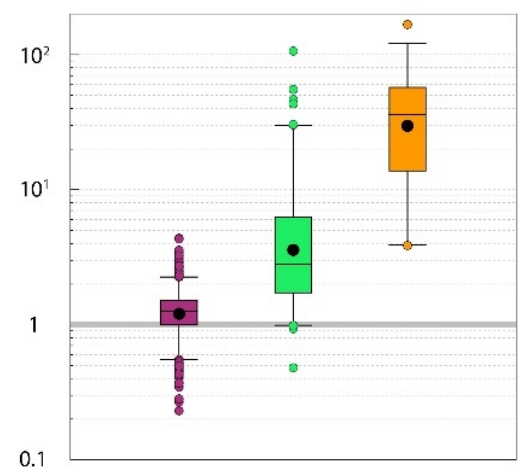

$\Delta \mathrm{Bi}$

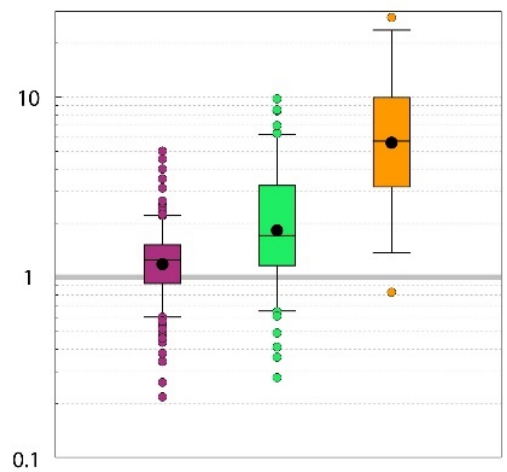

$\Delta \mathrm{Te}$

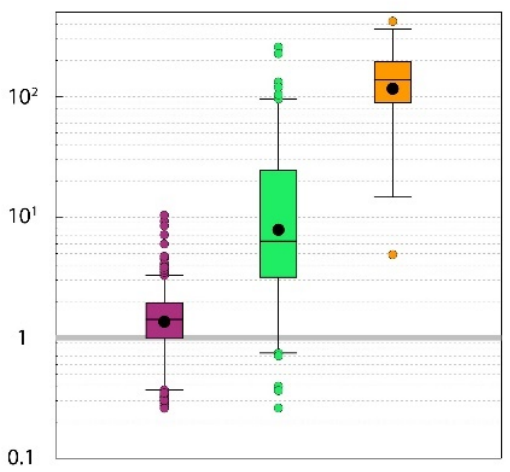

$\Delta$ As

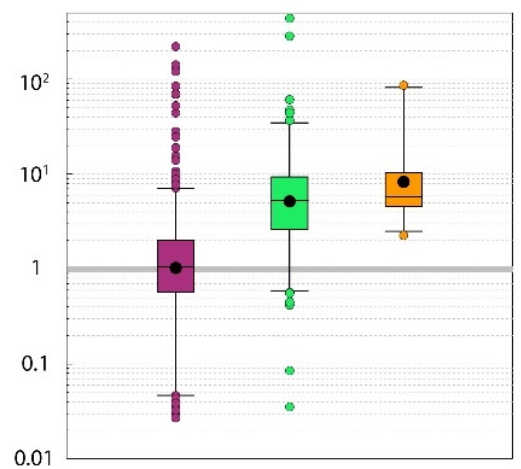

$\Delta \mathrm{Mo}$

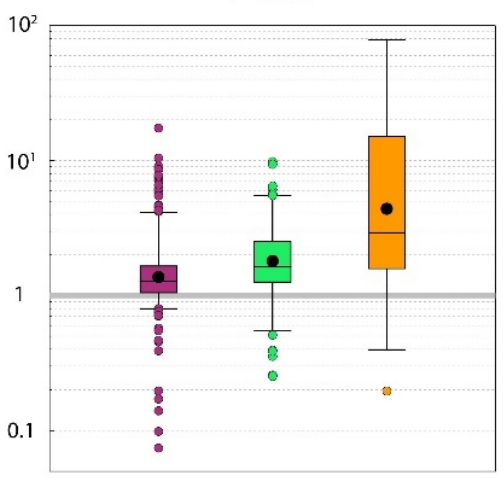

$\Delta \mathrm{W}$

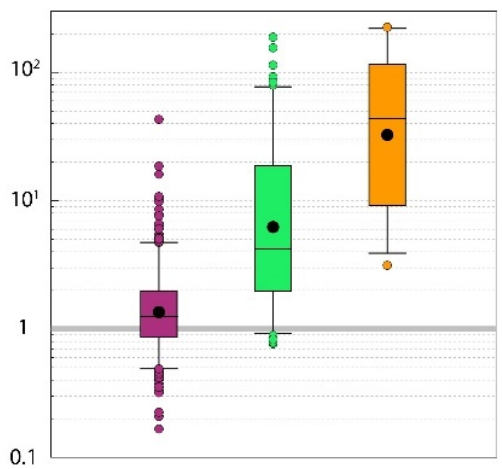

$\Delta \mathrm{Sb}$

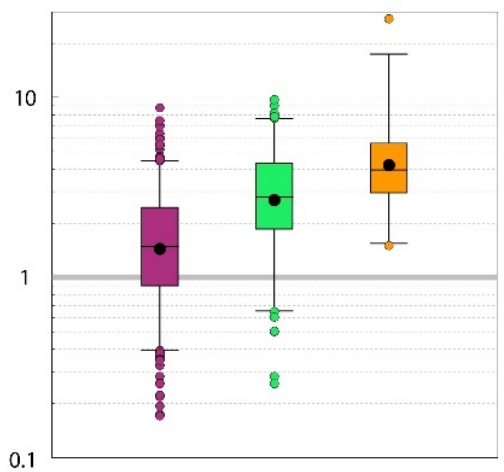

$\triangle \mathrm{Pb}$

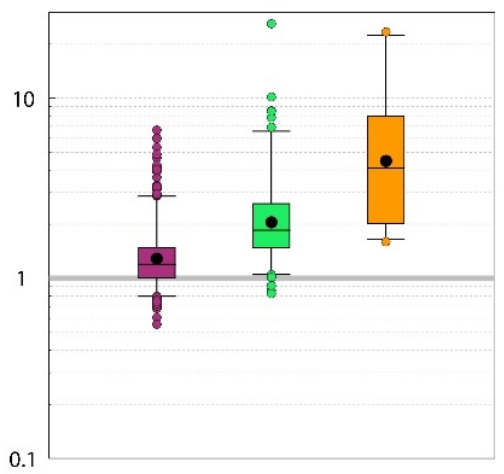

Proximal potassic alteration

- Distal potassic-sericitic alteration

- Background metasedimentary rocks

Figure 9: A compilation of box and whisker diagrams illustrating mass changes produced by hydrothermal alteration for select trace elements in the metasedimentary rocks of the Malartic district. The samples were divided into three categories according to alteration characteristics, from background (in purple), to distal (in green) and proximal (in orange) alteration zones. 


\begin{tabular}{|c|c|c|c|c|c|c|c|c|c|c|c|c|c|c|c|c|c|c|c|}
\hline & $\mathrm{Au}$ & $\mathrm{K}$ & $\mathrm{Na}$ & $\mathrm{K}+\mathrm{Na}$ & $\mathrm{Ca}$ & LOI & C & $\mathrm{S}$ & $\mathrm{Ag}$ & As & $\mathrm{Be}$ & $\mathrm{Bi}$ & $\mathrm{Cu}$ & Mo & $\mathrm{Pb}$ & $\mathrm{Sb}$ & $\mathrm{Se}$ & $\mathrm{Te}$ & w \\
\hline $\mathrm{Au}$ & 1 & & & & & & & & & & & & & & & & & & \\
\hline $\mathrm{K}$ & 0.35 & 1 & & & & & & & & & & & & & & & & & \\
\hline $\mathrm{Na}$ & 0.24 & -0.29 & 1 & & & & & & & & & & & & & & & & \\
\hline $\mathrm{K}+\mathrm{Na}$ & 0.51 & 0.62 & 0.54 & 1 & & & & & & & & & & & & & & & \\
\hline $\mathrm{Ca}$ & 0.32 & -0.02 & 0.41 & 0.28 & 1 & & & & & & & & & & & & & & \\
\hline LOI & 0.53 & 0.57 & 0.04 & 0.50 & 0.40 & 1 & & & & & & & & & & & & & \\
\hline C & 0.51 & 0.49 & 0.19 & 0.56 & 0.51 & 0.84 & 1 & & & & & & & & & & & & \\
\hline $\mathrm{s}$ & 0.66 & 0.56 & 0.29 & 0.72 & 0.35 & 0.75 & 0.64 & 1 & & & & & & & & & & & \\
\hline $\mathrm{Ag}$ & 0.62 & 0.45 & 0.19 & 0.55 & 0.28 & 0.66 & 0.54 & 0.82 & 1 & & & & & & & & & & \\
\hline As & 0.03 & 0.14 & \begin{tabular}{ll|}
-0.11 \\
\end{tabular} & 0.06 & 0.05 & 0.19 & 0.14 & 0.10 & 0.07 & 1 & & & & & & & & & \\
\hline $\mathrm{Be}$ & 0.58 & 0.63 & 0.19 & 0.69 & 0.31 & 0.74 & 0.70 & 0.70 & 0.59 & 0.10 & 1 & & & & & & & & \\
\hline $\mathrm{Bi}$ & 0.48 & 0.43 & 0.14 & 0.47 & 0.24 & 0.60 & 0.46 & 0.72 & 0.57 & 0.02 & 0.57 & 1 & & & & & & & \\
\hline $\mathrm{Cu}$ & 0.06 & 0.02 & 0.01 & 0.02 & 0.17 & 0.10 & 0.02 & 0.17 & 0.19 & -0.02 & 0.09 & 0.00 & 1 & & & & & & \\
\hline Mo & 0.22 & $\begin{array}{l}0.28 \\
\end{array}$ & 0.09 & 0.31 & 0.19 & 0.40 & 0.29 & 0.41 & 0.37 & -0.01 & 0.39 & 0.65 & -0.14 & 1 & & & & & \\
\hline $\mathrm{Pb}$ & 0.34 & 0.35 & 0.20 & 0.47 & 0.18 & 0.45 & 0.41 & 0.50 & 0.44 & 0.00 & 0.53 & 0.64 & -0.06 & 0.50 & 1 & & & & \\
\hline $\mathrm{Sb}$ & 0.20 & 0.31 & 0.09 & 0.35 & 0.19 & 0.40 & 0.36 & 0.43 & 0.31 & 0.28 & 0.27 & 0.24 & 0.04 & 0.11 & 0.16 & 1 & & & \\
\hline $\mathrm{Se}$ & 0.32 & 0.32 & 0.19 & 0.44 & 0.31 & 0.41 & 0.42 & 0.59 & 0.43 & 0.08 & 0.45 & 0.44 & 0.35 & 0.23 & 0.36 & 0.24 & 1 & & \\
\hline $\mathrm{Te}$ & 0.66 & 0.55 & 0.21 & $\begin{array}{l}0.65 \\
\end{array}$ & 0.28 & 0.70 & 0.60 & $\begin{array}{l}0.87 \\
\end{array}$ & 0.94 & 0.07 & 0.68 & 0.64 & 0.11 & 0.39 & 0.50 & 0.32 & 0.44 & 1 & \\
\hline W & 0.64 & 0.38 & 0.28 & 0.56 & 0.28 & 0.53 & 0.49 & 0.63 & 0.59 & 0.01 & 0.53 & 0.43 & 0.00 & 0.22 & 0.38 & 0.19 & 0.28 & 0.70 & 1 \\
\hline
\end{tabular}

Figure 10: Pearson correlation matrix of the mass change values (enrichment factors) calculated for select major and trace elements in the metasedimentary rocks of the Malartic district $(n=596)$. 

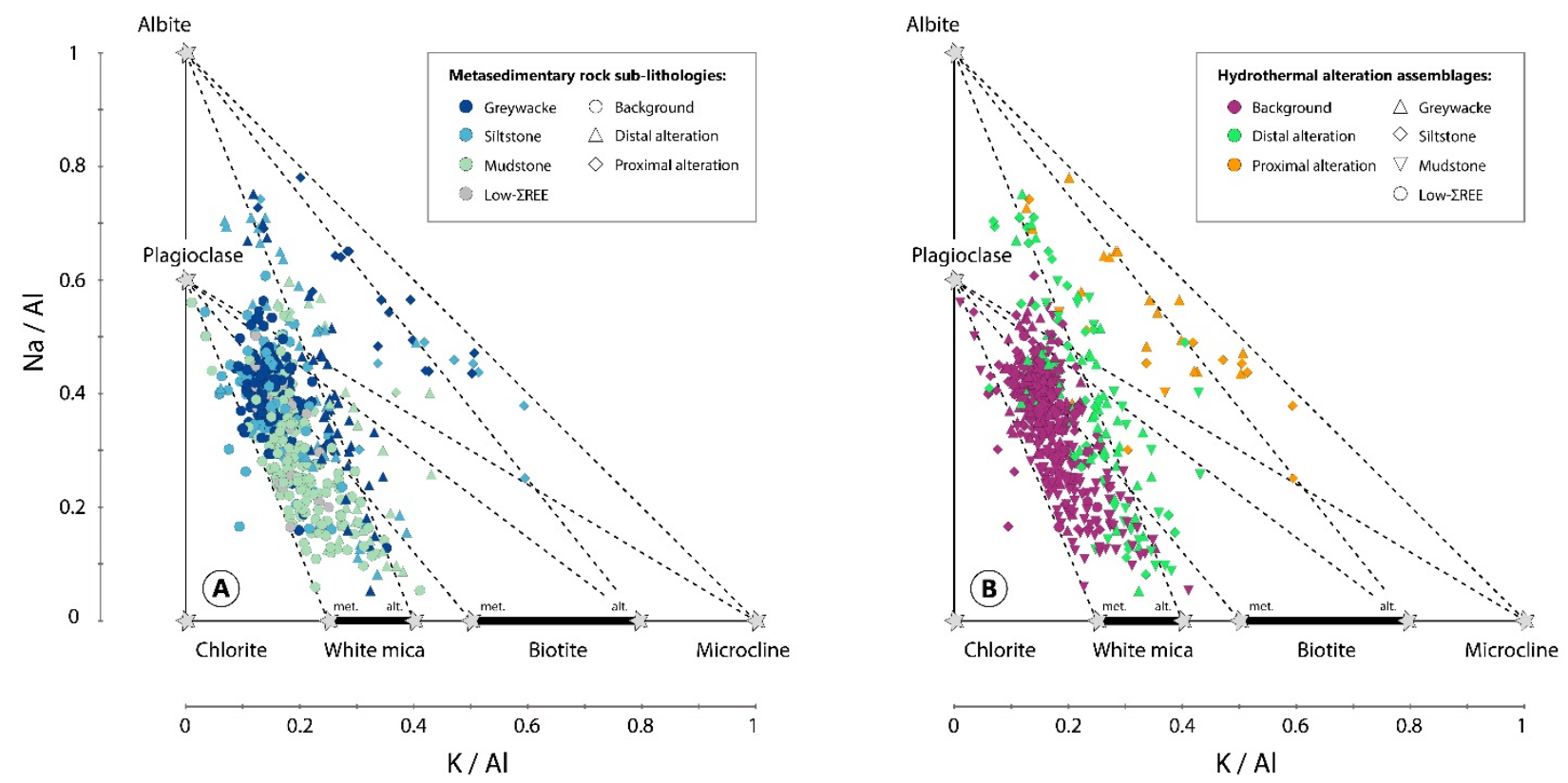

Figure 11: Binary plots of alkali/aluminium molar ratios (Na/Al vs. K/Al) for background and altered metasedimentary rocks of the Malartic district $(n=596)$. A: The effects of primary sedimentary features on whole-rock molar element ratios. Samples are grouped into four categories based on lithological characteristics, namely greywacke (dark blue), siltstone (medium blue), mudstone (green) and low $\sum R E E$ (grey) metasedimentary rocks. B: The effects of hydrothermal alteration on whole-rock molar element ratios. The samples are grouped into three categories based on alteration characteristics, from background (purple), to distal (green) and proximal (orange) alteration zones. Bold lines for biotite and white mica represent the range of mineral compositions determined from electron microprobe analyses (Gaillard et al., 2018). Abbreviations: alt: altered; met: metamorphic. 

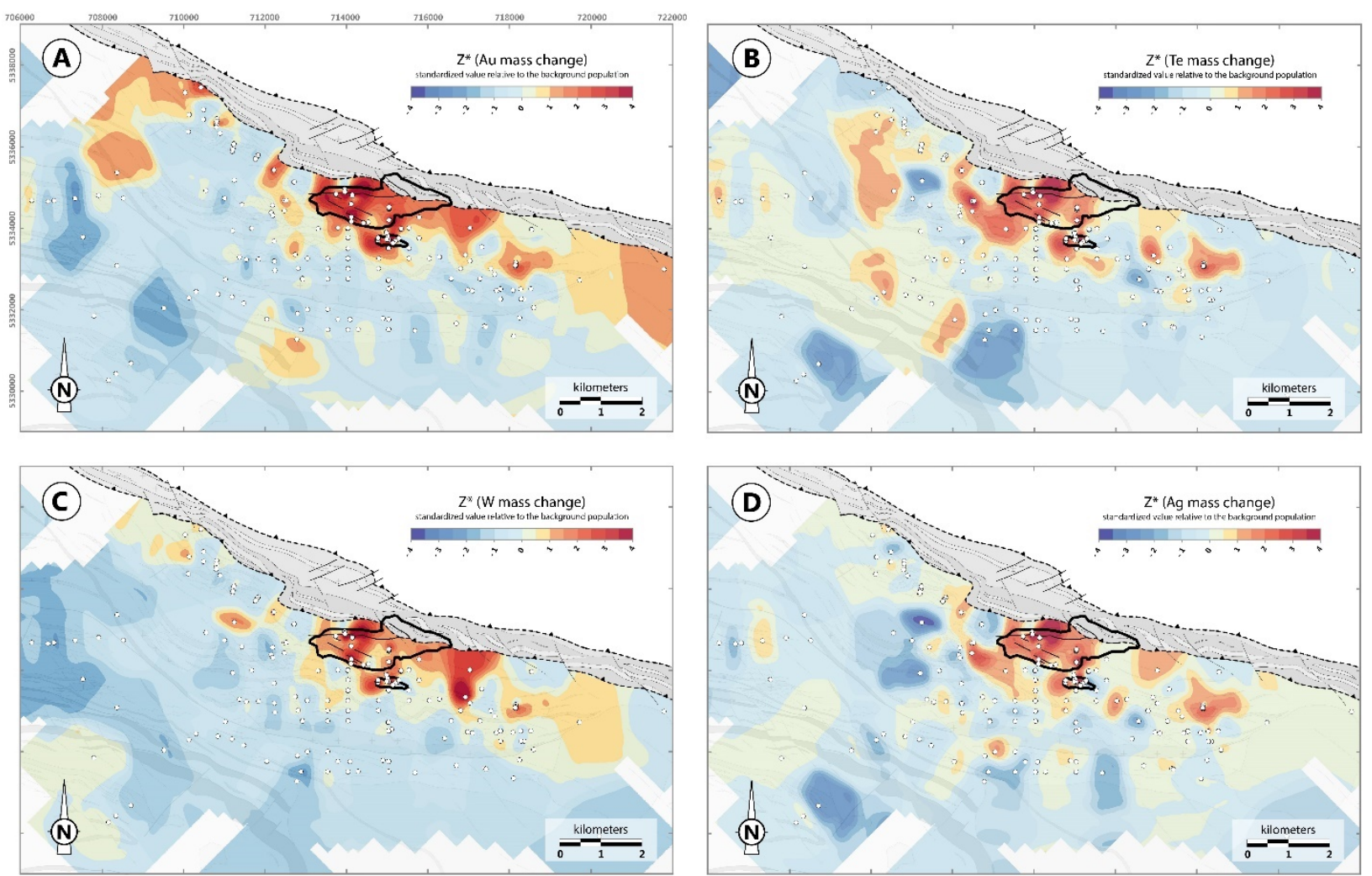

Figure 12: A series of interpolated lithogeochemical maps illustrating mass changes associated with hydrothermal alteration in the metasedimentary rocks of the Malartic district. The mass change results for $A u(A), T e(B), W(C)$ and $A g(D)$ are expressed in terms of standard deviation distance relative to the background population mean $\left(Z^{*}\right)$. See text for details on the calculation method. 

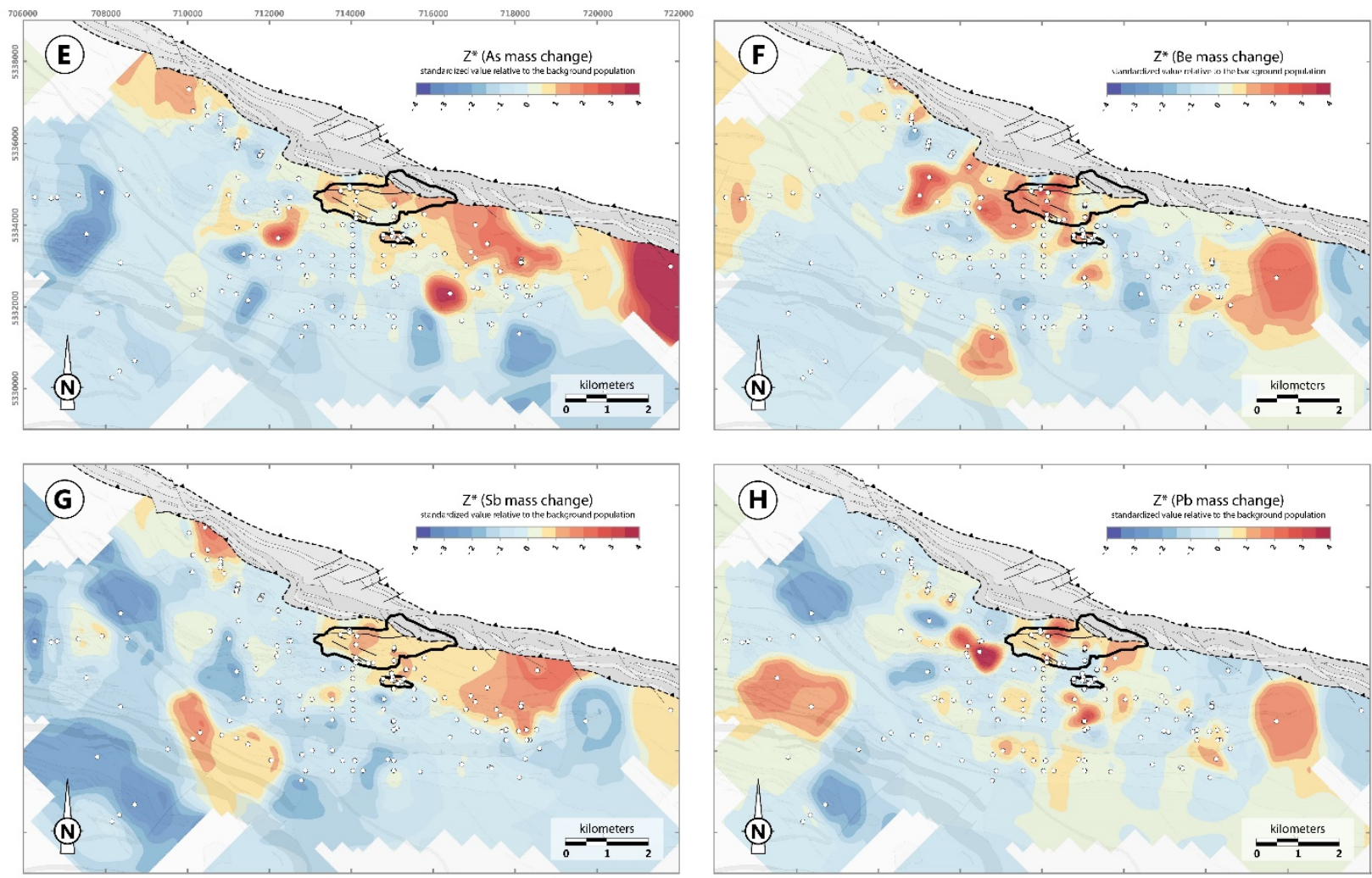

Figure 12 (continued): A series of interpolated lithogeochemical maps illustrating mass changes associated with hydrothermal alteration in the metasedimentary rocks of the Malartic district. The mass change results for $\mathrm{As}(\mathrm{E}), \mathrm{Be}(\mathrm{F}), \mathrm{Sb}(\mathrm{G})$ and $\mathrm{Pb}(H)$ are expressed in terms of standard deviation distance relative to the background population mean ( $\left.Z^{*}\right)$. See the text for details on the calculation method. 

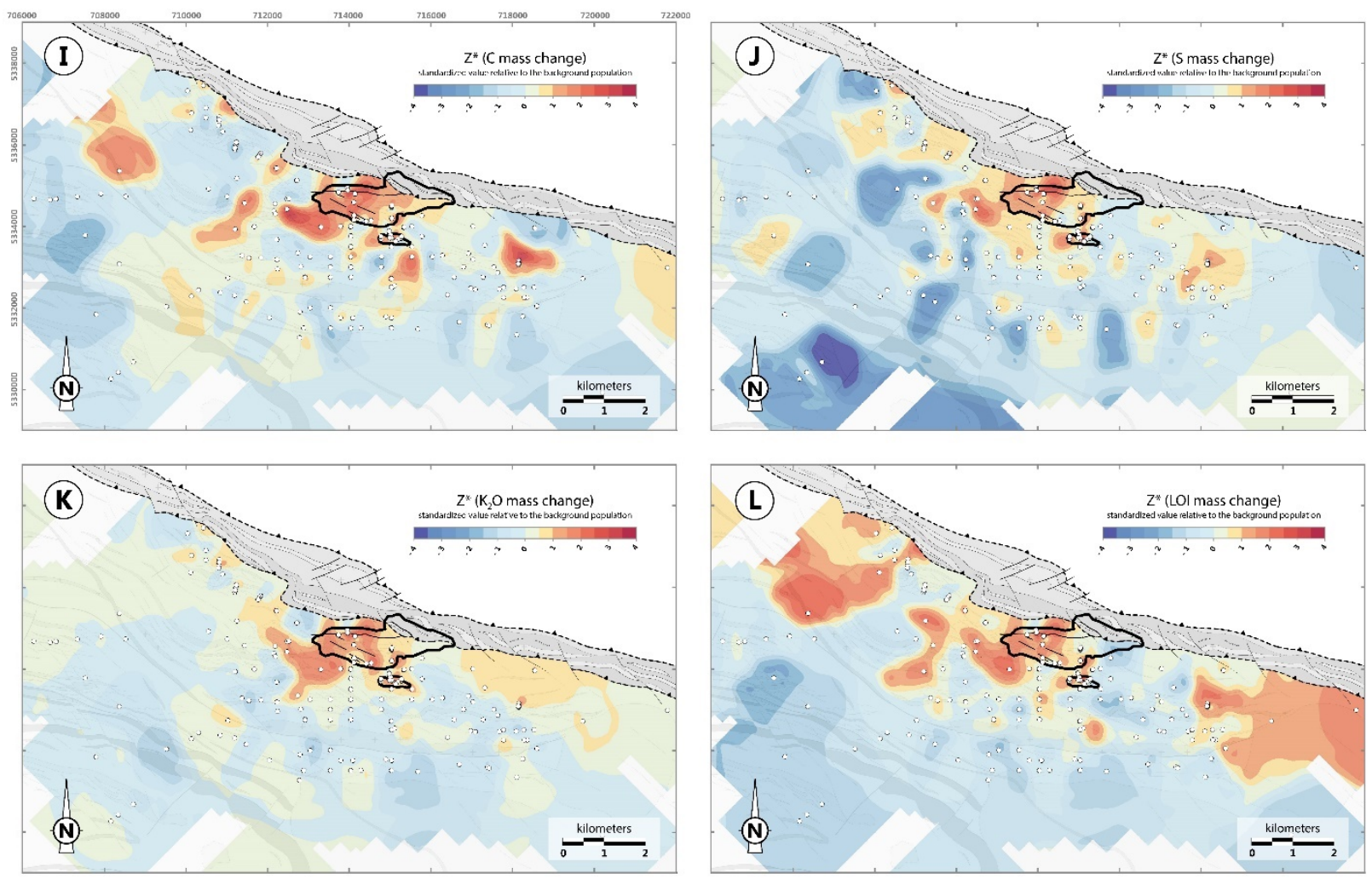

Figure 12 (continued): A series of interpolated lithogeochemical maps illustrating mass changes associated with hydrothermal alteration in the metasedimentary rocks of the Malartic district. The mass change results for $C(I), S(J), K_{2} O(K)$ and $L O I(L)$ are expressed in terms of standard deviation distance relative to the background population mean $\left(Z^{*}\right)$. See the text for details on the calculation method. 
APPENDICES 

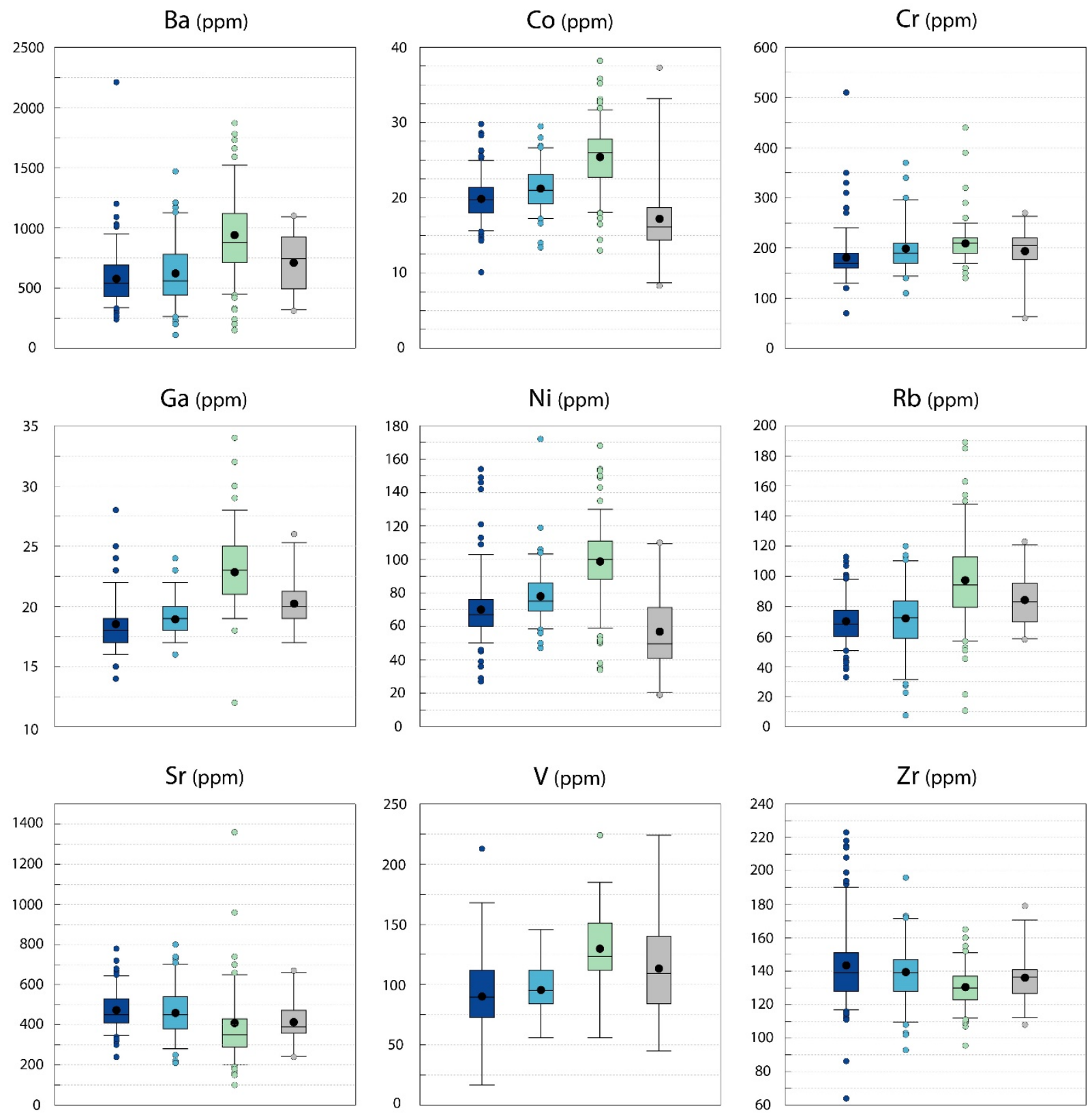

$$
\begin{aligned}
& \text { Metasedimentary rock sub-lithologies: } \\
& \text { - Greywacke Mudstone } \\
& \text { - Siltstone } \bigcirc \text { Low- LREE }
\end{aligned}
$$

Appendix 1: A compilation of box and whisker plots showing the primary whole-rock lithogeochemical variations (for minor elements) among the main grain size fractions of the Pontiac Group metasedimentary rocks (background population; $n=443$ ). The samples were separated into four sub-lithologies, namely greywacke (dark blue; $n=171$ ), siltstone (medium blue; $n=87$ ), mudstone (green; $n=159$ ) and low $\sum R E E$ (grey; $n=26)$ sediments. The bulk-rock sediment compositions are shown to display systematic variations with decreasing grain size. 


\begin{tabular}{|c|c|c|c|c|c|c|c|c|c|c|c|c|c|c|c|c|c|c|c|}
\hline & $\mathrm{Au}$ & $\mathrm{K}$ & $\mathrm{Na}$ & $\mathrm{K}+\mathrm{Na}$ & $\mathrm{Ca}$ & LOI & C & $\mathrm{S}$ & $\mathrm{Ag}$ & As & $\mathrm{Be}$ & $\mathrm{Bi}$ & $\mathrm{Cu}$ & Mo & $\mathrm{Pb}$ & $\mathrm{Sb}$ & $\mathrm{Se}$ & $\mathrm{Te}$ & w \\
\hline $\mathrm{Au}$ & 1 & & & & & & & & & & & & & & & & & & \\
\hline K & 0.55 & 1 & & & & & & & & & & & & & & & & & \\
\hline $\mathrm{Na}$ & 0.08 & $\begin{array}{r}-0.39 \\
\end{array}$ & 1 & & & & & & & & & & & & & & & & \\
\hline $\mathrm{K}+\mathrm{Na}$ & 0.67 & 0.50 & 0.48 & 1 & & & & & & & & & & & & & & & \\
\hline $\mathrm{Ca}$ & 0.24 & -0.19 & 0.47 & 0.29 & 1 & & & & & & & & & & & & & & \\
\hline LOI & 0.66 & 0.54 & -0.14 & 0.41 & 0.15 & 1 & & & & & & & & & & & & & \\
\hline $\mathrm{C}$ & 0.70 & 0.48 & 0.09 & 0.56 & 0.32 & 0.77 & 1 & & & & & & & & & & & & \\
\hline $\mathrm{S}$ & 0.65 & 0.39 & 0.19 & 0.62 & 0.25 & $\begin{array}{l}0.59 \\
\end{array}$ & 0.52 & 1 & & & & & & & & & & & \\
\hline $\mathrm{Ag}$ & 0.80 & 0.48 & 0.19 & 0.67 & 0.28 & 0.65 & 0.62 & 0.80 & 1 & & & & & & & & & & \\
\hline As & 0.54 & 0.29 & 0.01 & 0.32 & 0.18 & 0.44 & 0.54 & 0.43 & 0.44 & 1 & & & & & & & & & \\
\hline $\mathrm{Be}$ & 0.70 & 0.54 & 0.10 & 0.67 & 0.20 & 0.73 & 0.74 & 0.54 & 0.61 & 0.38 & 1 & & & & & & & & \\
\hline $\mathrm{Bi}$ & 0.53 & 0.34 & 0.11 & 0.40 & 0.15 & 0.53 & 0.42 & 0.66 & 0.67 & 0.28 & 0.42 & 1 & & & & & & & \\
\hline $\mathrm{Cu}$ & -0.06 & -0.01 & -0.05 & -0.10 & 0.01 & -0.03 & -0.08 & 0.22 & 0.07 & 0.03 & -0.08 & -0.05 & 1 & & & & & & \\
\hline Mo & 0.34 & 0.38 & 0.07 & 0.37 & -0.05 & 0.32 & 0.29 & 0.30 & 0.37 & 0.10 & 0.34 & 0.44 & -0.16 & 1 & & & & & \\
\hline $\mathrm{Pb}$ & 0.50 & 0.31 & 0.22 & 0.59 & 0.22 & 0.48 & 0.56 & 0.52 & 0.56 & 0.25 & 0.63 & 0.47 & -0.13 & 0.34 & 1 & & & & \\
\hline $\mathrm{Sb}$ & 0.45 & 0.26 & 0.06 & 0.34 & 0.20 & 0.37 & 0.41 & 0.41 & 0.45 & 0.49 & 0.26 & 0.27 & 0.03 & 0.13 & 0.25 & 1 & & & \\
\hline $\mathrm{Se}$ & 0.37 & 0.26 & 0.12 & 0.39 & 0.22 & 0.41 & 0.34 & 0.62 & 0.49 & 0.26 & 0.41 & 0.46 & 0.20 & 0.29 & 0.41 & 0.25 & 1 & & \\
\hline $\mathrm{Te}$ & 0.82 & 0.54 & 0.12 & 0.69 & 0.21 & 0.66 & 0.64 & 0.75 & 0.88 & 0.41 & 0.67 & 0.67 & -0.04 & 0.39 & 0.55 & 0.38 & 0.50 & 1 & \\
\hline W & 0.78 & 0.43 & 0.28 & 0.67 & 0.27 & 0.57 & 0.61 & 0.60 & 0.71 & 0.44 & 0.60 & 0.50 & -0.06 & 0.35 & 0.44 & 0.44 & 0.35 & 0.71 & 1 \\
\hline
\end{tabular}

Appendix 2: Pearson correlation matrix of log-transformed mass change values (enrichment factors) calculated for select major and trace elements in the metasedimentary rocks of the Malartic district $(n=596)$. 